Bryant University

Bryant Digital Repository

6-4-2020

\title{
The Battle over Wastewater between Woonsocket and North Smithfield
}

Melissa Prosky

Bryant University, mprosky@bryant.edu

Follow this and additional works at: https://digitalcommons.bryant.edu/hassenfeldarticles

Part of the Education Commons

\section{Recommended Citation}

Prosky, Melissa, "The Battle over Wastewater between Woonsocket and North Smithfield" (2020). Staff and Faculty Journal Articles. Paper 1.

https://digitalcommons.bryant.edu/hassenfeldarticles/1

This Article is brought to you for free and open access by the Hassenfeld Institute for Public Leadership at Bryant Digital Repository. It has been accepted for inclusion in Staff and Faculty Journal Articles by an authorized administrator of Bryant Digital Repository. For more information, please contact dcommons@bryant.edu. 


\section{The Battle over Wastewater between Woonsocket and North Smithfield}

\section{Structured Abstract}

Purpose - This case study analyzes a protracted battle that took place between two Rhode Island municipalities over the use of a shared wastewater facility. It traces a five-year long dispute during which time the host community (Woonsocket) imposed a new host fee on the user communities (including North Smithfield). This paper highlights the challenges that may arise during the implementation of a long term inter-jurisdictional agreement.

Design/methodology/approach - This case study draws on interviews conducted with officials from the Rhode Island Department of Environmental Management, City of Woonsocket, and Town of North Smithfield. Additionally, it pulls from relevant legal documents, recordings and minutes from meetings of the Woonsocket City Council and North Smithfield Town Council, City Council resolutions, state legislation, and local press coverage.

Findings - There are numerous possible challenges associated with implementing an intermunicipal agreement. First, there is flexibility in the signed contracts, which can lead to ambiguities and conflict. Second, there is room for state-level entities to get involved in mediating and ending the dispute. This includes state agencies, the legislature, and the courts. However, as shown here, such involvement is not always productive. Finally, it is important for jurisdictions to maintain a clarity of purpose in the pursuit of getting to "yes." It is all too simple for officials within and among communities to fight among each other and get distracted by petty actions. At the end of the day, it is important to arrive at a resolution, however imperfect.

Research limitations/implications - This case took place in a context where relatively few governmental functions were regionalized. It would be less applicable in states with where such functions (e.g. waste management) are handled at the county level.

Practical implications - This study is highly applicable to state and local officials charged with implementing interlocal agreements. Jurisdictions need to be proactive about updating their contracts upon expiration, rather than letting them lapse. Relatedly, there needs to be effective (and civilized) communication among public officials.

Originality/value - The paper provides a real world example of the challenges associated with achieving shared services, including an imperfect resolution.

\section{Introduction}

In 1977, the City of Woonsocket and the Town of North Smithfield entered into a thirty-year inter-jurisdictional agreement (IJA) for wastewater disposal. Under the terms of the arrangement, the newly built wastewater facility was located in Woonsocket. North Smithfield, 
along with neighboring Massachusetts towns Bellingham and Blackstone, contracted with Woonsocket for service. The formation of the U.S. Environmental Protection Agency (EPA) and passage of the Clean Water Act prompted the agreement, according to Angelo Liberti, Chief of Surface Water Protection for the RI Department of Environmental Management (DEM). ${ }^{1}$ Federal grant money was available to construct municipal wastewater treatment plants for proper wastewater disposal based on studies which were then called "Section 308 basin plans." These plans included evaluation of regional solutions. From there, communities formed regional commissions and IJAs for wastewater facility construction, operation, and maintenance.

The 1977 contract between Woonsocket and North Smithfield contained several significant provisions concerning the governance of the facility.

1) The thirty-year timeframe represented the minimum commitment. Upon the conclusion of that period, the parties would remain in the contract unless they arranged for termination. Either of the parties would be required to provide three years notice to end the contract.

2) If it became necessary for capital improvements to take place, Woonsocket would consult with North Smithfield to "determine jointly the nature of the improvements, the cost and financing thereof, the allocation of such costs among participating municipalities and other factors." Improvements and cost allocations would only proceed in accordance with the agreement.

3) The contract called for the creation of an official board for adopting the facility's policies and programs. The board would consist of at least 10 representatives total across all participating municipalities, based on the cost incurred by the jurisdiction.

4) If Woonsocket contemplated any increases in expenditures for plant maintenance or operation resulting in increased costs to North Smithfield, the parties would hold a gjoint conference.

5) In the event of disagreement, the Woonsocket City Council and the North Smithfield Board of Sewer Commissioners would convene to work on the matter. If discord continued, either of the jurisdictions could file a request for arbitration. ${ }^{2,3}$

\footnotetext{
${ }^{1}$ Unless otherwise stated, quotes from individuals came from interviews. Interviewees included Angelo Liberti, Richard Coen, John DeSimone, Gary Ezovski, Paulette Hamilton, and Brian Newberry. David Igliozzi provided much of the legal documentation. Members of the Woonsocket City Council and the North Smithfield Town Council declined to participate.

${ }^{2}$ Wastewater Disposal Service Contract between City of Woonsocket and Town of North Smithfield, December 7, 1977.

${ }^{3}$ This arrangement aligned with multiple provisions of RI General Laws. This included: 45-14-1- Power to Assess Charges, which stated that "each city and town is authorized and empowered to enact ordinances assessing users of sewers or sewer systems of the cities and towns, a charge for the use of the sewers or sewer systems in an amount that bears a reasonable relation to the cost to the city or town of the service rendered to the users" and 46-12.2-10- RI Infrastructure Bank/Powers of Local Governmental
} 
In 2007, thirty years following the original signing, the towns had not drafted a replacement agreement. Thus, everything continued as usual, subject to the three-year termination by either side. $^{4}$

The DEM Imposes New Mandates; Woonsocket Plans for Facility Upgrades

On June 27, 2008, Woonsocket entered into a consent agreement with the DEM relating to the Rhode Island Pollutant Discharge Elimination System permit for the wastewater treatment plant. This agreement required that Woonsocket meet new limits for nitrogen, phosphorus and other performance standards by March 31, 2014. ${ }^{5}$ Subsequently, Woonsocket entered into a modified consent agreement with the DEM on March 3, 2011.6

Woonsocket needed financing to upgrade the plant in compliance with the new DEM mandates. This served as the City's impetus for devising new agreements, according to Woonsocket's Counsel Richard Coen. Reflecting back on the time, he said that Woonsocket needed to understand whether the neighboring communities were in it for the "long haul," or if they planned to explore other options for wastewater service. The new IJAs took into account capital costs (upgrades), as well as actual usage.

On January 18, 2011, the Woonsocket City Council unanimously passed Resolution 2011-07, which authorized the amendment of the wastewater treatment plant agreement with Veolia (the operator of the plant at the time) to address phosphorus limits. Under the terms of the resolution, Woonsocket would pay Veolia up to $\$ 250,000$ a year for system upgrades as part of a DEM consent agreement in order to comply with the permit for the RI Pollutant Discharge Elimination System. ${ }^{7}$ The following month, the Woonsocket City Council unanimously passed Resolution 2011-20 authorizing the entry into the aforementioned DEM consent agreement. ${ }^{8}$ Woonsocket Plans for Facility Upgrades, but Not Everyone is on the Same Page

\footnotetext{
Units, which allowed for a local governmental unit to enter into agreements and charge fees for the use of any wastewater system.

${ }^{4}$ As of 2018, North Smithfield had 3,552 Equivalent Dwelling Units (EDU's). Of all the homes and businesses in the Town, about one-third were on the sewer system, while the rest had septic or cesspool. Information provided by Maura Beck, North Smithfield Water and Sewer Coordinator.

${ }^{5}$ See Woonsocket, RI, Resolution 2011-20 (2011). The DEM issued the final permit in June 2005, which included more stringent nitrogen and phosphorus limits, and as a result, the City needed to upgrade the wastewater treatment facility. According to Liberti, "Once we issue the final permits, the permits basically require immediate compliance, because the statutory deadline to meet any water quality waste limits is passed... Obviously, they [Woonsocket] can't immediately comply with the stricter limits, so they appealed the permit." From there, the parties entered into a consent agreement, which drove Woonsocket's scheduling to do their facility planning, design, and construction.

6 See Woonsocket, RI, Resolution 2011-99 (2011).

7 See Woonsocket, RI, Resolution 2011-07 (2011).

8 See Woonsocket, RI, Resolution 2011-20 (2011).
} 
The issue of official roles and responsibilities concerning the wastewater facility proved to be a recurring theme among Woonsocket leaders. Members of the City Council and the administration frequently wrestled over questions of policy and process. Councilman Daniel Gendron and Department of Public Works (DPW) Director Sheila McGauvran engaged in a testy exchange during the July 18, 2011 Woonsocket City Council meeting. The City Council was in the process of considering an ordinance providing for the issuance of wastewater revenue bonds in an amount not to exceed \$4,000,000. ${ }^{9}$ The two went back and forth about Woonsocket's costs associated with the reserve capacity for the plant upgrades. ${ }^{10}$

Further strife between the Woonsocket City Council and administration was on display during the second round of discussion of the $\$ 4$ million finance ordinance the following month. In particular, Councilmen Christopher Beauchamp, Gendron, and Roger Jalette complained about the manner in which the administration had handled the ordinance. Beauchamp did not understand the urgency of passing the ordinance that night or why the IJAs were not part of the package given to the Council. Mayor Fontaine and DPW Director McGauvran explained that the ordinance was necessary for lining up the financing in order to comply with the DEM consent order. The administration did not include the new IJAs because those were still in draft form.

Mayor Leo Fontaine expressed major frustration in responding to Councilman Jalette's complaint about the lack of a work session prior to the vote. He said:

"If the Council wishes to have work sessions, I'll have work sessions; I'll have work sessions on every piece of legislation that we propose... We've had three weeks from first passage to now. You've had plenty of time to call if you had questions after first passage, you could've called... I don't mind, and I think maybe I'll work with the Council President so that we will schedule a work session for every piece of legislation that we propose, because I just don't want to continue going through this process where we put something up, everybody seems to be okay with it up front, then some comments from the public come up, and then the Council comes back and says, 'We weren't given all the information.'"'11

Despite the tensions, the City Council passed the ordinance through to the second round. Mayor Fontaine signed it on August 11, 2011. At this point, none of the other towns had participated in any plant discussions.

\footnotetext{
${ }_{9}^{9}$ According to the Woonsocket charter, in order to enact an ordinance, it must be approved at two consecutive regular City Council meetings, "except ordinances for the levying of taxes or for the appropriation of money, which shall require only one passage and shall become effective immediately when signed by the mayor." A resolution only needs to pass the City Council once (no mayoral approval necessary).

${ }^{10}$ Woonsocket City Council Meeting, July g18, 2011.

${ }^{11}$ Woonsocket City Council Meeting, August 9, 2011.
} 


\section{The First Mention of a Potential Plant Host Fee}

On November 21, 2011, the Woonsocket City Council held a work session regarding progress on the continually fraught area of new IJAs. New IJAs were necessary in order to obtain a lowinterest loan from the Clean Water Finance Agency. ${ }^{12}$ Consultant Paul Eisenhardt advised the City Council to split the costs of plant improvements among the jurisdictions according to capacity. However, Councilmen Gendron and Albert Brien complained that Woonsocket had the burden of hosting the plant, and should therefore be able to charge a host fee from the neighboring communities. Woonsocket would be the first community in the state to impose a host fee for the use of its wastewater treatment plant. Eisenhardt and DPW Director McGauvran warned that changing the IJAs to include a potential host fee could put Woonsocket at risk of losing out on financing. Mayor Fontaine stated, "I think we need to understand that we're all on the same team here...I think we do need to take into account the repercussions." 13 That same day, Mayor Fontaine signed Ordinance Chapter 7645, which approved the financing of improvements to the treatment plant in an amount not to exceed $\$ 26$ million. This ordinance had passed the Woonsocket City Council for the first time on October 17, 2011 and the second time on November 14, 2011, with minimal discussion or controversy. ${ }^{14}$

\section{Other Jurisdictions Learn about Fee Increases}

In the meantime, neighboring communities were just beginning to learn about potential wastewater fee increases. ${ }^{15}$ The Valley Breeze published a letter from North Smithfield Town Administrator Paulette Hamilton on December 1, 2011 in which she expressed her dismay for proposed fee increases, attributed to the DEM mandate. She wrote, "The R.I. Dept. of Environmental Management is imposing an unrealistic requirement in these uncertain economic times. It would seem to me that the emphasis should be focused on the state, which

\footnotetext{
12 Now known as the RI Infrastructure Bank.

${ }^{13}$ Sandy Phaneuf, "Council to Vote on Authorizing Interjurisdictional Wastewater Agreements," Woonsocket Patch, November 23, 2011, https://patch.com/rhode-island/woonsocket/council-to-vote-onauthorizing-interjurisdictional-wa4b399f9c3d.

14 Woonsocket, RI, Ordinance Chapter 7645 (2011). By March 2012, Woonsocket secured a $\$ 30$ million loan from the Clean Water Finance Agency to begin upgrades. See Sandy Phaneuf, "As Sewer Rates Rise, Officials Question Pollution Upstream," The Valley Breeze, March 1, 2012. Although a jurisdiction cannot borrow money without having the IJAs in place, this unsettled matter did not seem to affect their ability to obtain financing.

${ }^{15}$ It is not entirely clear how neighboring communities learned about fee increases at this point. However, as mentioned in the preceding section, Woonsocket officials had begun discussing this possibility. Their statements were covered in the local media.
} 
once again has placed an unfunded mandate on a city [Woonsocket] that is already struggling..."16

At the December 19, 2011 Woonsocket City Council meeting, officials discussed the controversial rollout of the proposed host fees. During the citizens "good and welfare" portion of the meeting, an official from Blackstone complained that he had only just learned about the new host fees. Following a heated conversation among council members and the administration, the Council decided to table the resolution that would have amended the three IJAs. ${ }^{17}$ Councilmen Beauchamp, Robert Moreau, and Gendron expressed differing concerns about the institution of host fees. Beauchamp and Moreau had concerns about Blackstone's apparent lack of knowledge regarding the new fee. Mayor Fontaine wanted no further approval delays. Counsel to Woonsocket Richard Coen said that while he had already spoken to the attorneys for each of the three neighboring jurisdictions to notify them of upcoming discussion regarding future IJA modifications, he lacked direction from the Council regarding next steps.

Meanwhile, Councilman Gendron continued to impress upon the need for a host fee:

“Because Woonsocket has established this phenomenal infrastructure, which, when we get this mandate that we have to improve our wastewater treatment by [the] DEM, that falls on Woonsocket's shoulders... So the other communities are affected but this is Woonsocket's problem, because it's Woonsocket's wastewater treatment plant. It's not a regional plant." 18

Despite the temporary tabling of the resolution, the City Council continued to progress towards implementation of a host fee.

The Woonsocket City Council Formalizes the New Host Fees

On February 20, 2012, the Woonsocket City Council passed a resolution instructing the mayor and director of public works to draft amended IJAs for North Smithfield, Bellingham, and Blackstone-this time with the host fees explicitly articulated. Each town's host fee was to

\footnotetext{
${ }_{16}$ Paulette Hamilton, Letter to the Editor, "Waste Water Fees must be Equitable," The Valley Breeze, December 1, 2011. On June 23, 2011, Mayor Fontaine signed the annual Ordinance containing the wastewater treatment user charges for each of the applicable jurisdictions. In the case of North Smithfield, this amount totaled $\$ 746,629$ for the time period of July 1, 2011 through June 30, 2012. See Woonsocket, RI, Ordinance Chapter 7611 (2011). According to Administrator Paulette Hamilton, and her successor, Administrator Gary Ezovski, North Smithfield always paid their user fees on time during the years in which the dispute took place. It was only the host fees, subject to challenge, that were unpaid. In subsequent years, the user charges for North Smithfield totaled \$716,032 ('12-'13), \$858,635 ('14-'15), $\$ 1,065,955$ ('15-'16), and $\$ 1,159,634$ ('16-'17). The user charge for '13-'14 was not available. See Woonsocket, RI, Ordinance Chapters 7682 (2012), 7752 (2014), 7818 (2015), and 7915 (2016).

${ }_{17}$ Note: A copy of the resolution was not available.

18 Woonsocket City Council Meeting, December 19, 2011.
} 
represent a percentage of the cost of plant improvements, based on wastewater contributions, as follows:

- North Smithfield- 7\%

- Bellingham- $2.75 \%$

- Blackstone- $1.5 \%$

In total, the jurisdictions would be responsible for $11.25 \%$ of plant improvement costs. The three communities had 20 business days to accept the new agreement, after which time Woonsocket intended to issue a three-year termination notice. ${ }^{19}$ The new agreement did not contain any provisions for discussion of the new fee structure.

\section{Continued Interactions between Woonsocket and the DEM}

At the March 5, 2012 Woonsocket City Council meeting, Councilman Moreau complained about how the DEM was treating Woonsocket: "The state right now, the way they're treating Woonsocket, we've had our state aid cut, we've had more state mandates than ever before. They're mandating a wastewater treatment plant, they're mandating a water treatment plant. Everything's got to be done with no funding from them at all. When does it stop? When do they come and help us?" 20

The Woonsocket delegation to the RI State House attempted to mitigate the situation. On March 15, Representatives Lisa Baldelli-Hunt, Jon Brien, and Robert Phillips introduced H 7966, "An Act Relating to Waters and Navigation." It called for Woonsocket to delay implementation of the DEM standards until after December 31, 2017, due to financial constraints. A week later, the House Municipal Government Committee recommended passage, but no further action occurred. ${ }^{21}$ The DEM had testified against the bill, but negotiations with the City were already on-going regarding an additional extension and the DEM ended up giving Woonsocket one last, two-year extension. ${ }^{22}$ From that point on, Woonsocket's compliance was "smooth sailing," according to the DEM's Angelo Liberti.

\footnotetext{
${ }^{19}$ Woonsocket, RI, Resolution 2012-18 (2012).

${ }^{20}$ Woonsocket City Council Meeting, March 5, 2012. At that same meeting, the City Council passed Resolution 2012-13, which created a Wastewater Treatment Plant Advisory Committee. The Committee's duties were advisory, rather than binding. See Woonsocket, RI, Resolution 2012-23 (2012). According to Richard Coen, their work pertained to vendors for the wastewater plant project, not the new IJAs. ${ }^{21}$ Rhode Island (State). Legislature. General Assembly. An Act Relating to Waters and Navigation (2012H7966). March 15, 2012.

22 The DEM gave Woonsocket until January 2017 to complete plant upgrades. Director Janet Coit allowed for the extension since the City had two major overlapping projects- the facilities for wastewater and water treatment, as well as the fiscal crisis due to significant deficits in the City's school department. See March 21, 2012 letter from Mayor Fontaine to Director Coit and her response dated March 23, 2012. In a separate memo to Representative Jon Brien, Coit emphasized that "the precedent that would be set by this legislation has the very real potential to cripple the department's executive authority to manage
} 
Woonsocket Continues Working Toward Implementing a Host Fee

At the January 22, 2013 Woonsocket City Council meeting, Councilman Albert Brien expressed his continued discontent with North Smithfield. He was bothered that North Smithfield had the means to undertake successful economic development thanks to Woonsocket's comprehensive infrastructure. As an example, he pointed to the vibrant commercial activity in Park Square. Brien expressed this as evidence that North Smithfield should pay a premium in order to use the wastewater treatment plant. ${ }^{23}$

In March, the Woonsocket City Council reviewed a revised resolution to amend the IJAs. Instead of outlining the host fees as percentages per the February 20, 2012 resolution, the new agreements contained the values as dollar amounts. Councilman Gendron argued with DPW Director McGauvran and Mayor Fontaine about the calculations of the included figures. The two insisted that the numbers reflected the costs of implementing a $\$ 37$ million project. Gendron agreed to accept the calculations only after Brien confirmed them. ${ }^{24}$

Following the long exchange, the Woonsocket City Council unanimously passed a revised resolution instructing the mayor and director of public works to draft amended IJAs with North Smithfield, Bellingham, and Blackstone. The new resolution contained two major changes. First, Woonsocket would direct the host fee to the general fund, rather than the annual debt on plant improvements. Second, instead of outlining the host fee in terms of percentages, the new resolution specified the dollar amounts. North Smithfield would pay a host fee of $\$ 194,000 .{ }^{25}$ Furthermore, Woonsocket would increase the host fee on an annual basis by the CPI for all urban customers in the Boston area issued in July each year. ${ }^{26}$

\section{Tensions Brew between North Smithfield and Woonsocket}

In May 2013, the Town of North Smithfield began to grapple with the issue of the new host fee during its own Town Council meetings. By this point, it was well past the 20-day period of consideration. In fact, it had been over a year since Woonsocket formally proposed the host fee in the resolution. Councilman Paul Zwolenski asked Administrator Hamilton to contact the State directly to find out whether the new fee structure was legal..$^{27}$ In her interview, Hamilton remarked that the new fee did not go over well with either herself or the Town Council. A new

water quality and administer the National Pollutant Discharge Elimination System (NPDES) program, at the hands of the legislative branch and to the overall detriment of the Bays and its watersheds."

${ }^{23}$ Woonsocket City Council Meeting, January 22, 2013.

${ }^{24}$ Woonsocket City Council Meeting, March 4, 2013.

${ }^{25}$ Bellingham and Blackstone were billed $\$ 76,000$ and $\$ 42,000$ respectively.

${ }_{26}$ Woonsocket, RI, Resolution 2013-21 (2013). Woonsocket used the base CPI of 246.326 established in July 2012.

${ }_{27}$ North Smithfield Town Council Meeting Minutes, May 20, 2013. 
annual fee would raise the rates for users considerably. She found that having the host fee directed to Woonsocket's general fund was particularly troubling:

"I think that it would have been even more palatable, as disdainful as it was to have it [the host fee] at all, if it had gone back to the sewer fund to provide upgrades to the system that would not have to be borne by the ratepayers... But clearly the City [Woonsocket] was in financial constraints and needed to garner as much additional revenue as possible... I know and was told unequivocally that you never comingle those funds."

The DEM was not aware of the host fee until after Woonsocket started appending it to bills for the communities, according to the agency's Liberti. North Smithfield contacted the DEM asking if this was legal. The DEM said there was nothing in the state regulations forbidding it-even though none of the other communities in RI charged a host fee for use of their treatment facilities. Meanwhile, Administrator Hamilton said that, in general, there was a lot of friction between her and the Town Council on a number of issues. This made it difficult to negotiate with Woonsocket in a civilized manner.

At the June 3, 2013 Woonsocket City Council meeting, members uttered their frustrations, not only with the Town of North Smithfield, but also with the state-appointed Budget Commission. ${ }^{28}$ Although DPW Director McGauvran noted that the last resolution gave the neighboring communities 20 days to provide a response to Woonsocket, Councilmen John Ward and Gendron blamed the Commission for delays and confusion regarding the timeframe for notification. Councilman Brien once again defended Woonsocket's proposed distribution of the host fee in the general fund. ${ }^{29}$ At the July 1, 2013 Woonsocket City Council meeting, Councilmen Moreau, Gendron, and Beauchamp confirmed with Mayor Fontaine that Woonsocket sent out the three-year cancellation notice to North Smithfield. ${ }^{30}$

During the July 15, 2013 North Smithfield Town Council meeting, members went into executive session regarding the wastewater agreement. No motions were made or votes taken on the issue. This would mark just one of many instances in which the Town Council decided to deal

\footnotetext{
${ }^{28}$ On May 27, 2012, the Woonsocket City Council passed Resolution 2012-58, which requested that the RI Division of Municipal Finance and the RI Director of Revenue, in consultation with the RI Auditor General, establish a Budget Commission for the City of Woonsocket. This was in response to the financial crisis caused by School Department deficits, loss of cash flow, inability to submit a final proposed FY '13 budget, among other things. Like the advisory committee, their work pertained mainly to vendors for the wastewater plant project, not the new IJAs, as mentioned by Richard Coen. The Commission disbanded on March 19, 2015. See Woonsocket, RI, Resolution 2012-58 (2012); Sandy Seoane, "Woonsocket Budget Commission Disbands, Leaves Behind Fiscal Adviser and Five-Year Plan," The Valley Breeze, March 20, 2015.

${ }^{29}$ Woonsocket City Council Meeting, June 3, 2013.

${ }^{30}$ Woonsocket City Council Meeting, July 1, 2013.
} 
with the matter behind closed doors. Since there were no motions or votes, there were no available public minutes of the session. Records of this and other executive sessions remain sealed indefinitely. ${ }^{31}$

Woonsocket officials discussed the status of the three-year notice once again during the August 5, 2013 City Council meeting. Although the mayor said that he had not heard any response from North Smithfield, Councilman Ward did say that he had heard from the North Smithfield Town Council President that Woonsocket would have a response within 30 days. ${ }^{32}$

Additional time passed, and North Smithfield failed to approve the new IJA. During the September 3, 2013 City Council meeting, Councilman Gendron wanted to make clear that Woonsocket did not seek to "gouge its neighbors." He also expressed impatience with North Smithfield's lack of response. ${ }^{33}$ By the time the Woonsocket City Council met once again on October 7, North Smithfield was not any closer to signing onto the agreement. Councilman Gendron told Mayor Fontaine to notify North Smithfield that Woonsocket would start the clock on terminating the agreement. ${ }^{34}$

On October 21, 2013, DPW Director McGauvran sent out the official termination notice to Administrator Hamilton. The letter contained the threat: "As the Town [North Smithfield] is aware, the U.S. Environmental Protection Agency, the Rhode Island Department of Environmental Management and other federal and state agencies may impose fines or other penalties should the Town [North Smithfield] fail to ensure [in a timely manner] the proper disposal of its residents' wastewater immediately following the Wind-Down Period." 35 However, Administrator Hamilton learned from the DEM that there was no way to shut off service strictly to North Smithfield without closing down the entire system. ${ }^{36}$ Although she understood that there was no "master switch" to turn off use of the sewer system, many worried constituents thought this might happen.

In the meantime, North Smithfield had contracted with Joe Casali Engineering Inc. to study wastewater treatment alternatives, should they decide not to contract with Woonsocket.

${ }^{31}$ Subsequent dates in which the Town Council held executive sessions on the subject included August 19, 2013, October 7, 2013, July 21, 2014, August 4, 2014, October 6, 2014, March 2, 2015, April 6, 2015, May 4, 2015, June 1, 2015, June 8, 2015, August 3, 2015, November 2, 2015, December 7, 2015, April 4, 2016, May 16, 2016, July 18, 2016, September 19, 2016, November 21, 2016, and December 19, 2016.

32 Woonsocket City Council Meeting, August 5, 2013.

${ }_{33}$ Woonsocket City Council Meeting, September 3, 2013.

${ }^{34}$ Woonsocket City Council Meeting, October 7, 2013.

${ }^{35}$ Letter from Woonsocket Department of Public Works Sheila McGauvran to North Smithfield Town Administrator Paulette Hamilton, October 21, 2013.

${ }^{36}$ Furthermore, Liberti confirmed that neither state nor federal agencies were going to impose fines on North Smithfield in this situation. 
Administrator Hamilton explained that North Smithfield had to explore alternatives for the purpose of due diligence. She said, "We looked everywhere, we talked to other communities, we talked to engineers, we talked to environmentalists. Really, it was a very comprehensive approach to looking at alternatives for the safety of our people and what made sense to the Town." North Smithfield officials discussed the Casali study's two options during the December 16 Town Council meeting. First, North Smithfield could connect to Burrillville's plant. However, Burrillville did not have the capacity to handle North Smithfield's wastewater. Second, North Smithfield could construct its own new plant. Construction would cost about $\$ 30$ million, with an approval process of five to eight years. ${ }^{37}$ Casali recommended that North Smithfield use Woonsocket's facility, as it was the most affordable option." 38

\section{A New Administration Arrives in Woonsocket, but Tensions with the City Council Remain}

Members of the Woonsocket City Council and the Mayor engaged in a contentious discussion regarding the status of North Smithfield during the March 3, 2014 Council meeting. Points of contention included the application of the host fee and the process of coming to an agreement. Councilman Gendron objected to newly elected Mayor Lisa Baldelli-Hunt's conversation with Administrator Hamilton regarding the host fee. ${ }^{39}$ He stated, "It is our wastewater treatment plant and where we put those funds is our choice. And the least that we can do for the people of Woonsocket that live in the neighborhood of that plant is to help offset ever so slightly the impact that they have to endure from that smell." Mayor Baldelli-Hunt disagreed with that characterization. Councilman Jalette reminded the Mayor that the administration could not unilaterally make an agreement with a neighboring jurisdiction. Only the City Council with Budget Commission approval had that authority. ${ }^{40}$

At the September 2, 2014 Woonsocket City Council meeting, Councilman Gendron and Mayor Baldelli-Hunt engaged in another heated argument over the status of the North Smithfield IJA. Mayor Baldelli-Hunt said that while Bellingham and Blackstone were resolved, North Smithfield still had many questions regarding their IJA. She indicated that North Smithfield had issues with legal terminology, rather than financial concerns, and that the attorneys indicated that it would probably take another week for them to sign on. As the conversation progressed, things quickly boiled over. Here is an excerpt of that exchange:

\footnotetext{
${ }^{37}$ North Smithfield officials met the DEM in November 2013 to discuss constructing its own facility. See letter from Joe Casali Engineering, Inc. to North Smithfield Town Administrator Paulette Hamilton, December 13, 2013.

38 North Smithfield Town Council Meeting Minutes, December 16, 2013.

${ }^{39}$ Hamilton mentioned in her interview that the Baldelli-Hunt administration was very willing to meet with them and provide information that made the fee "a little bit more palatable."

${ }^{40}$ Woonsocket City Council Meeting, March 3, 2014.
} 
Councilman Gendron: I am just puzzled why Bellingham has already paid their bill, Blackstone is on track to pay their bill, and North Smithfield still hasn't signed their contract.

Mayor Baldelli-Hunt: Because North Smithfield quite frankly said that they have been asking for help, for months prior to this administration coming in-

Councilman Gendron: Okay but you have been here since December so let's talk from December on-

Mayor Baldelli-Hunt: You know, Dan, don't be condescending to me. Okay, let me tell you something. If you have a question, you can call my office; you don't need to grandstand when you come to a Council meeting.

[Continued angry cross talk between Baldelli-Hunt and Gendron]

Council President Brien: Please, do not speak over one another.

Mayor Baldelli-Hunt: Call my office and I will answer your question.

Councilman Gendron: No! I am asking my question here. I am asking you, Mayor, a question that deserves to be answered.

Mayor Baldelli-Hunt: Dan, in nine months, the only time you have a question other than a stop sign is when you come to a Council meeting. So if you would like the particulars on the IJA, you can call my office and I will make sure that I have the exact answer that you are looking for.

Councilman Gendron: I will continue to ask my questions at the meetings. No, you are not answering my question, you are telling me something else. And don't laugh. ${ }^{41}$

At the October 20, 2014 Woonsocket City Council meeting, the schism between the Council and administration continued on full display. To Councilman Gendron, an IJA was a straightforward matter, akin to purchasing Gatorade from the local Walmart. While shopping there, the customer sees the set price and decides whether to proceed with the purchase. If North Smithfield disagreed with the terms of the agreement, the town could simply walk away. Solicitor Michael Marcello argued, on the other hand, that an IJA was supposed to be a negotiated agreement. Councilman Gendron worried that if negotiations dragged on, North Smithfield would not take the termination notice seriously. In addition, Solicitor Marcello found it unrealistic to think that Woonsocket was just going to cut off service. ${ }^{42}$

Woonsocket Continues to Finance Plant Improvements

${ }^{41}$ Woonsocket City Council Meeting, September 2, 2014.

${ }^{42}$ Woonsocket City Council Meeting, October 20, 2014. 
On February 24, 2015, Mayor Baldelli-Hunt signed Ordinance Chapter 7799, authorizing the Woonsocket Treasurer and the Mayor to borrow a maximum of \$14 million from the Rhode Island Clean Water Finance Agency for financing improvements to the plant. Woonsocket previously issued $\$ 30$ million in bonds to finance the project, making the total estimated project cost $\$ 44$ million. ${ }^{43}$

\section{Tensions between the Two Jurisdictions Boil Over}

The Woonsocket DPW Director notified the Woonsocket City Council at their May 4, 2015 meeting that North Smithfield officials sent notice that they were not going to pay. He said, "If I have to shut the spigot off, I will." 44

Meanwhile, the North Smithfield Town Council drove the dispute into an entirely different matter: the Blackstone Valley bike path. The Army Corps of Engineers was set to extend the path, which passed through Woonsocket and North Smithfield, up to the Massachusetts state line. The North Smithfield Town Council opted to hold up a bikeway easement over North Smithfield's three-acre plot of land in response. Town Council President Robert Boucher made the following statement to the Valley Breeze, "We're sick of being bullied and this was the only way I could think of to make a statement. They need something and I felt like, we're not going to give it to you. We're not going to give it to them if they're going to hold us up like a bunch of gangsters." Robert Ericson, North Smithfield's planner, discouraged the Town Council from holding up the easement: "I understand there are other issues that need to be worked out with Woonsocket, but to use this as leverage for that is a very bad idea...It's a beautiful bike path. Why would you want to keep the North Smithfield residents from sharing that?"45

During her interview, Administrator Hamilton noted that relations between North Smithfield and Woonsocket got particularly combative after that statement. "He [Robert Boucher] was adamantly opposed to giving Woonsocket a dime... he really put them on edge. So it didn't help him in negotiations, that's for sure. And then it became more of a contentious thing. Up until that point it really wasn't. It was really frustrating, but it wasn't as contentious." She also mentioned that Boucher insulted Woonsocket on the radio.

On May 11, 2015, Casali Engineering contacted North Smithfield regarding three additional alternatives to the Woonsocket facility. ${ }^{46}$ The first involved connecting to the Town of Smithfield's treatment plant. Casali found that Smithfield did not have the capacity to process

\footnotetext{
43 Woonsocket, RI, Ordinance Chapter 7799 (2015).

44 Woonsocket City Council Meeting, May 4, 2015. See Sandy Seoane, "Council Passes Bike Path Easement, but Tension between Neighbors over Wastewater Escalates," The Valley Breeze, May 27, 2015. 45 Sandy Seoane, "Tied Vote Holds up Bike Path over Feud with Woonsocket," The Valley Breeze, May 7, 2015.

${ }^{46}$ Apart from the previously discussed options of a Burrillville connection and new plant construction.
} 
additional wastewater. Second, the firm deemed the Narragansett Bay Commission facility, which served other communities in the Blackstone Valley, unfeasible due to the cost of infrastructure and the potential for river and wetland crossings. Finally, the company Synagro Technologies would not be able to serve North Smithfield's needs because the company was only able to process treated wastewater and biosolids, not untreated effluent, which is what would come out of North Smithfield. ${ }^{47}$ Given these circumstances, Casali recommended that North Smithfield continue to use the Woonsocket facility. ${ }^{48}$

City Council President Albert Brien said he was offended by the "gangsters" comment during the May 18, 2015 Woonsocket City Council meeting. He thought that Woonsocket had every right to impose the host fee. Brien stated, "Clearly, the [North Smithfield] Town Council President was moving forward without having any of the facts before him, which is not unusual." 49

On June 1, 2015, the North Smithfield Town Council voted to approve a grant of easement to the Army Corps of Engineers for the bike path. ${ }^{50}$

By December 2015, with less than a year until agreement termination, the DEM pressed Woonsocket to resolve the dispute. ${ }^{51}$

\section{$\underline{\text { A New Year Rolls Around, with New Attempts at Resolution }}$}

During the January 4, 2016 Woonsocket City Council meeting, Councilman Gendron sought to address the residents of North Smithfield directly. He stated:

“We're not your enemy. We are your neighbor, and we have always tried to work for what's best for the entire community. And unfortunately, when you hear, coming from newspaper articles or from the elected officials in your community, we' re sometimes represented as evil people. We're not. We're your neighbors, we want to work together, and we're looking for nothing but a resolution... But this whole arrangement brings us back to exactly the original percentages that were agreed upon back in 1977. And every time I talk to people and meet with people from North Smithfield or Blackstone or Bellingham, and you're given the opportunity to explain the details of it, I haven't had a single individual say that Woonsocket's being unrealistic... Now I understand that you need to exhaust every resource that you have [referring to North Smithfield hiring Casali to explore alternatives]... I would like to be sure that the residents of North

\footnotetext{
${ }^{47}$ Synagro already provided sludge incineration services in Woonsocket.

${ }^{48}$ Letter from Joseph A. Casali to North Smithfield Town Administrator Paulette Hamilton, May 11, 2015.

49 Woonsocket City Council Meeting, May 18, 2015.

${ }^{50}$ North Smithfield Town Council Meeting Minutes, June 1, 2015.

${ }^{51}$ Joseph B. Nadeau, “Woonsocket, N.S. Spar over Sewer,” The Call (Woonsocket, RI), December 24, 2015.
} 
Smithfield don't hold us- this Council, this administration, or the City of Woonsocketresponsible for what happens when that spigot gets shut off. There was a three-year notice given. There's been no secrets about this...I'm pretty sure that the people of North Smithfield realize that we are friends, and we've always wanted this to work. And maybe you need to discuss that with individuals in your own community... We still welcome you into our home, and all we need to do is facilitate the execution of what the other two communities have already done..." 52

On January 14, 2016, Woonsocket Administrative Aide Michael Annarummo sent a letter to North Smithfield Administrator Hamilton about North Smithfield potentially exiting the facility. ${ }^{53}$ He explained that Woonsocket recently completed a Facilities Plan, "to reflect North Smithfield's prior indication of its intent to participate in the upgraded system." Therefore, the departure of North Smithfield would result in necessary modifications to the Plan. In addition, he noted that Woonsocket might have to revise the Comprehensive Community Plan. In order to mitigate the costs associated with the changes, North Smithfield would be charged $\$ 100,000$, reflecting the amount Woonsocket's professional engineering firm said it would cost to address the issues. The letter continued, "While these are not the only damages I anticipate the City will incur, I wanted to alert you promptly to this consequence of the upcoming cessation of

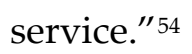

Five days later, Administrator Hamilton publicly urged the North Smithfield Town Council to sign the Woonsocket IJA. She said, "I just want to go on record as saying that I think we should be signing the agreement and that if we need to dispute the host fee at any point later we can turn to litigation if that is within the purview of the council." Nevertheless, North Smithfield Town Council President Boucher continued to pursue the possibility of formulating an agreement with Burrillville. ${ }^{55}$

\section{North Smithfield Attempts to Assert Itself in the Legislature}

On February 1, 2016, the North Smithfield Town Council voted unanimously to send the legislation creating the Blackstone Valley Wastewater Treatment Authority to their state legislative delegation. ${ }^{56}$ In describing the proposal, Town Council President Boucher stated:

\footnotetext{
52 Woonsocket City Council Meeting, January 4, 2016.

53 This served as a follow-up to the December 29, 2015 letter.

${ }^{54}$ Letter from Woonsocket Administrative Aide Michael Annarummo to North Smithfield Town Administrator Paulette Hamilton, January 14, 2016.

${ }^{55}$ Joseph Fitzgerald, "Administrator Advises Town should Sign Agreement for Wastewater Treatment," The Call (Woonsocket, RI), January 26, 2016.

${ }^{56}$ North Smithfield Town Council President Boucher first publicly mentioned this legislation during the June 1, 2015 Town Council meeting. See North Smithfield Town Council Meeting Minutes, June 1, 2015.
} 
"The problem is that the City of Woonsocket turned something that was supposed to be a partnership into a dictatorship... we can also get the PUC [Public Utilities

Commission] involved because currently there is no legal address [sic] to control any costs that the City of Woonsocket may make and dictate to the Town of North Smithfield and other partners of the so-called wastewater treatment plant which includes the town of Blackstone, Bellingham as well." 57

Representative Brian Newberry of North Smithfield introduced H 7813, "Blackstone Valley Wastewater Treatment Authority Act" on March 2, 2016. The legislation declared that the most efficient method for consolidating and coordinating wastewater treatment resources was through, "the creation of a public instrumentality which shall have the authority to evaluate, plan, operate, and respond to the need to provide wastewater treatment to the residents of the area served." The proposed regional authority board of directors would consist of five members, two of whom would be appointed by the Mayor of Woonsocket, and one appointed by the Town Council or Board of Selectmen for the other three jurisdictions. Members would each serve four-year terms. ${ }^{58}$ Representative Newberry said that it was a parallel attempt to put pressure on Woonsocket after the City's delegation sponsored a separate bill in $2014 .{ }^{59}$ On March 17, Town Council President Boucher testified in support of the legislation. He said, "Back in 1977 when the plant was constructed, this was supposed to be a regional wastewater treatment district... They are threatening us with not extending any of our lines in North Smithfield and we will be able to show how shabbily the City of Woonsocket is treating its former partners in the plant." 60

While the North Smithfield Town Council worked to support the legislation, Woonsocket officials advocated in opposition. During the March 21, 2016 Woonsocket City Council Meeting, Councilman Gendron expressed bewilderment as to who came up with a study indicating that there was a need to consolidate and coordinate wastewater resources for the Blackstone Valley. He characterized this as an attempt to confiscate Woonsocket's infrastructure. Councilman Beauchamp added, “...it's very hard for me to be nice in circumstances when we're called gangsters, we're holding them hostage. If we held them hostage and it was such an erroneous

${ }^{57}$ North Smithfield Town Council Meeting, February 1, 2016.

${ }^{58}$ Rhode Island (State). Legislature. General Assembly. An Act Relating to Towns and Cities-Blackstone Valley Wastewater Treatment Authority Act (2016-H7813). March 2, 2016.

${ }^{59}$ On June 12, 2014, Representative John DeSimone of Woonsocket, along with Representatives Stephen Casey, Michael Morin, Robert Phillips, and Spencer Dickinson introduced legislation (H 8311) that would have amended property subject to taxation. At the time, Woonsocket was considering the purchase of land in North Smithfield for the development of a water treatment facility. Had development of the property proceeded, the legislation would have allowed Woonsocket to pay taxes to North Smithfield at a discount. The House Finance Committee considered the bill, but it did not advance any further. ${ }^{60}$ Joseph Nadeau, "N. Smithfield Officials Want new Wastewater Agency- Council Balks at Plant Fees Owed to Woonsocket, Wants State to Set up Regional Authority," The Call (Woonsocket, RI), March 17, 2016. 
agreement, Blackstone and Bellingham would have never signed." City Council President Brien referred to the legislation as the most "devious, disingenuous public document" that he had ever seen in more than 45 years of public service. He added:

"This is a disgrace. It is a disgrace to decency. It is a disgrace to cooperation that we've had in place for many, many years. And I cannot speak, I cannot emphasize enough the need for us to appeal to our legislative delegation to a sense of equity at the General Assembly and have this bill defeated. And shame on you, Mr. President of the North Smithfield Town Council. Call the talk shows later this week and tell us all of the excuses you have to deal in a very underhanded, unprofessional manner. Shame on you." 61

During the meeting, the Woonsocket City Council unanimously passed Resolution 2016-50, which requested that the Woonsocket delegation to the General Assembly vote and advocate in opposition to H 7813 (Blackstone Valley Wastewater Treatment Authority Act). The Resolution stated that, "The City, which is the primary user of the City's wastewater treatment facility, has absolutely no interest in ceding control of its facility to a Blackstone Valley Wastewater Treatment Authority." 62

On March 24, 2016, the House Municipal Government Committee recommended the measure be held for further study, and no further action occurred.

\section{North Smithfield Demands Arbitration}

On April 4, 2016, the North Smithfield Town Council voted unanimously for a resolution authorizing the Town Solicitor to demand arbitration under the IJA with Woonsocket. The resolution stated that Woonsocket, "with full knowledge that the Town has no practical option but to continue to utilize the Facility and has relied upon the City's legal and equitable duty to treat the Town fairly and equitably as its partner-has abused its effective monopoly power over the manner by which the Town is compelled to dispose of its wastewater and breached the Contract..." The resolution went on to explain the two major ways in which the breach of contract occurred. First, Woonsocket failed to create an official board for the purpose of adopting facility policies and programs. Second, North Smithfield alleged that Woonsocket unilaterally imposed onerous new financial terms, including the host fee. Therefore, North Smithfield sought to address these concerns through the arbitration process, as described in the 1977 agreement. ${ }^{63}$ During the public comment period, North Smithfield Planner Robert Ericson,

${ }^{61}$ Woonsocket City Council Meeting, March 21, 2016.

62 Woonsocket, RI, Resolution 2016-50 (2016).

${ }^{63}$ North Smithfield Town Council Meeting Minutes, April 4, 2016. 
speaking in opposition to this course of action, said that the whole process created an enormous amount of risk and uncertainty for economic development in North Smithfield. He said:

"I get calls every week wanting an explanation of what is going on. This arbitration with its timeline with the assumption that they [potential investors] will put off any activity till the arbitration is complete raises even more risk... And that's really my concern that this uncertainty... has the potential to push you over the edge if the other party is not willing to postpone their actions until after the arbitration is finished." 64

On June 6, 2016, Anthony Cottone, the outside Counsel for North Smithfield, sent a letter to Mayor Baldelli-Hunt and the DPW Director advising them that North Smithfield was demanding arbitration. ${ }^{65}$ Ten days later, Woonsocket's outside Counsel, Richard Coen, responded to Cottone's letter explaining that the demands were not arbitrable. The letter maintained that on October 21, 2013, Woonsocket provided notice of termination, effective November 1, 2016. “There are no conditions or requirements to establish cause in connection with the right to terminate pursuant to Section 5.02. The City's termination is proper as a matter of contract, statute and common law." Coen further wrote that North Smithfield could not make demands on a proposed new contract based on the old one. Finally, the letter mentioned that a voluntary regional board existed at one point, but was disbanded by mutual agreement. ${ }^{66}$

North Smithfield filed suit against Woonsocket in Rhode Island Superior Court on July 25, 2016. The Town sought an order compelling arbitration and injunctive relief in case Woonsocket denied them access to the facility while arbitration was pending. The document articulated the same concerns discussed in North Smithfield's Resolution demanding arbitration. ${ }^{67}$

On September 13, 2016, Judge Richard Licht ordered a motion to stay. This meant that all terms of the 1977 agreement would remain in place indefinitely. Woonsocket could not shut off wastewater services. Licht advised the two jurisdictions to engage in confidential, non-binding mediation. ${ }^{68}$ North Smithfield Solicitor David Igliozzi remained hopeful that the two sides would come to mutual agreement. ${ }^{69}$

${ }^{64}$ North Smithfield Town Council Meeting, April 4, 2016.

${ }^{65}$ Letter from Counsel Anthony F. Cottone for the Town of North Smithfield, RI to Woonsocket Mayor Lisa Baldelli-Hunt and Woonsocket Public Works Director, June 6, 2016.

${ }^{66}$ Letter from Woonsocket Counsel Richard Coen to North Smithfield Counsel Anthony F. Cottone, June 16, 2016.

${ }^{67}$ State of Rhode Island Superior Court Plaintiff's Memorandum in Support of Its Motion to Compel Arbitration and for Injunctive Relief (C.A. No. 16-3469), July 25, 2016.

${ }^{68}$ State of Rhode Island Superior Court Order Staying the Action Pending Possible Mediation (C.A. No. 16-3469), September 20, 2016.

${ }^{69}$ Russ Olivo, "N.S. to City: Take Your Sewer Bill, and Flush It," The Call (Woonsocket, RI), September 20, 2016. In addition to North Smithfield, Woonsocket had ongoing difficulties (although not to the same extent) with having Town of Blackstone pay their host fee for FY '14, the first year under their new 
The Court scheduled the first mediation between the two parties for October 27, 2016, according to public documents. ${ }^{70}$ Attorney Coen noted that the sessions were of varying lengths. Some involved updating the judge, while others were about getting the judge's insight on what the parties discussed..$^{71}$

\section{Leadership Changes Lead to New Hope}

Voters in the two communities made some leadership changes following the 2016 election. North Smithfield elected a new town administrator, along with two new members of the Town Council. Woonsocket elected two new City Council members. In addition, a new solicitor began his tenure in Woonsocket. During the November 21, 2016 Woonsocket City Council meeting, Council President Albert Brien and the DPW Director commented on the new North Smithfield Town Council being more conciliatory. ${ }^{72}$

On December 5, 2016, the North Smithfield Town Council voted unanimously to authorize the Town Administrator to establish a liaison with the City of Woonsocket to confidentially discuss the wastewater agreement. Although the liaison would not be authorized to make an agreement, this person would report to the Council any information gained. ${ }^{73}$ The goal was to help resolve the dispute faster than might otherwise occur. ${ }^{74}$

Officials from the two jurisdictions held two "informal" meetings. Participants included administrative representatives and council members from both communities. The purpose of the meetings was to deal with the terms of the settlement. ${ }^{75}$

Leaders from both communities remained optimistic about an imminent resolution. North Smithfield Town Council President Beauregard said there were no tensions between the jurisdictions like there had been in the past. He was hopeful that the two sides would come together to put the matter to rest. Woonsocket Council President Gendron said the communications between the two councils at that stage were significantly friendlier than in the past. North Smithfield Administrator Gary Ezovski said, “My ambition since getting elected

agreement. At the September 19, 2016 Woonsocket City Council meeting, Finance Director Christine Chamberland said that Blackstone had still not paid the host fee for FY '14, but had done so for FY '15 and '16. See Woonsocket City Council Meeting, September 19, 2016 and Blackstone Board of Selectman Meeting Minutes, November 29, 2016. This was eventually settled.

${ }^{70}$ Additional sessions were scheduled for January 17, 2017, February 10, 2017, and February 14, 2017.

${ }^{71}$ I was unable to confirm the complete list of individuals involved in the mediations.

72 Woonsocket City Council Meeting, November 21, 2016.

${ }^{73}$ North Smithfield Town Council Meeting Minutes, December 5, 2016.

${ }^{74}$ Joseph Nadeau, "North Smithfield Council to Seek Court Opinion on O'Hara," The Call (Woonsocket, RI), December 7, 2016.

${ }^{75}$ Based on the timing of press accounts, it appears that these took place in April 2017. See "Woonsocket, North Smithfield Settle Waste Dispute," The Valley Breeze, April 18, 2017. 
has been to accomplish agreement. I remain committed to that and believe we will do so."76 Woonsocket Solicitor John DeSimone said that when he started in the position in January 2017, he immediately wanted to resolve the situation. He added that there were no tensions.

\section{The Two Communities Formally Come to Resolution}

On April 17, 2017, 10 years after the original contract expired, the North Smithfield Town Council voted 4-1 (Councilman Paul Zwolenski voted no) to accept the terms of the settlement agreement and to authorize the Town Administrator to sign the new IJA. ${ }^{77}$ The following day, Woonsocket and North Smithfield issued a joint press release regarding the settlement. It read:

"The City of Woonsocket and the Town of North Smithfield reached an amicable settlement to the unfortunate dispute between the communities over a wastewater interjurisdictional agreement... After several years of disagreement that was sometimes the subject of unfortunate rhetoric, officials from both communities held a series of informal meetings that led to an agreement that settles all outstanding issues to the satisfaction of both communities, including those before the R.I. Superior Court."

Woonsocket Council President Gendron said that once officials engaged in informal conversations, "it became clear that the dispute was overblown and easily remedied." 78 North Smithfield Council President Beauregard affirmed, "The agreement is fair and equitable to both sides, but more importantly demonstrates the solid and productive relationship that exists between the two neighbors." 79 Speaking about this in 2018, Attorney Coen stated:

"I was impressed throughout the whole process with the commitment that certainly the City [Woonsocket] showed, and, I think, what North Smithfield showed to keep trying, and not draw lines in the sand. I think that that was the main reason that this got resolved without having to go through any further court proceedings. Judge Licht was really helpful in encouraging us to keep open minds, and challenging us to be creative in working through issues that seemed difficult to resolve."

However, in his interview, Administrator Ezovski said he was not happy with the outcome. He said:

\footnotetext{
${ }^{76}$ Sandy Seoane, "Beauregard: Waste Agreement with Woonsocket 'will be reached'- Neighboring Councils say Longstanding Dispute could be on its Way to Resolution," The Valley Breeze, April 13, 2017. Judge Licht was expected to issue a decision on April 11 as to whether or not Woonsocket had the right to terminate the contract, but delayed the verdict until April 24 in light of the discussions.

${ }^{77}$ North Smithfield Town Council Meeting Minutes, April 17, 2017. Judge Licht ended up not issuing a verdict since the jurisdictions settled the agreement out of court.

78 "Woonsocket, North Smithfield Settle Waste Dispute," The Valley Breeze, April 18, 2017.

${ }^{79}$ Sandy Seoane, “North Smithfield Signs Waste Agreement with Woonsocket,' The Valley Breeze, April 19, 2017.
} 
"My observation is that the City [Woonsocket] intent was clear, and it would not change its course from requiring a host fee, which frankly still doesn't sit well with the Town of North Smithfield. It's one of those things where we end up having to agree to disagree. But in the meantime, we're having to pay the bill. And to this day, I don't like the outcome, but we couldn't make it any better than it was."

Ezovski did not want North Smithfield to keep spending money on legal fees and recognized that the Court might not rule favorably in the future. He described Woonsocket as "immovable" on the issue of the host fee. Ezovski was especially displeased about Woonsocket directing the host fee to the general fund. He also pointed out that while there was supposed to be a regional board involved in governing the facility, it was actually controlled solely by Woonsocket. Ezovski added, "I don't think that anybody in North Smithfield wants to have anything but a good relationship with any of our neighbors." However, "I don't really like the final conclusion, but there are just things in life that you don't like...We've got to move on. They're our neighbors and they have the place where a vital service to our community takes place."

On May 15, 2017, the Woonsocket City Council unanimously passed resolution 2017-60, which ratified the terms of the settlement agreement and the new IJA. The two parties retroactively implemented the agreements, with an effective start date of June 30, 2014. In the final agreement, Woonsocket directed the new host fee to the general fund, and the annual bill increase remained the same as that which had been proposed from the start. Woonsocket did not put a regional board put into place. The City waived interest penalties on North Smithfield for the past due host fee amounts. Among many other provisions, the new agreement had sections concerning implementation and enforcement, methods of determining flows, collection of amounts payable, futures users and improvements, matters subject to conference between the parties, dispute resolution, remedies, and termination. The amended agreement had an expiration date of March 31, 2035. ${ }^{80}$

80 Woonsocket, RI, Resolution 2017-60 (2017). 


\section{Exhibit 1}

\section{Cast of Characters}

Michael Annarummo: Served various positions in the City of Woonsocket (1995-2016), including as Director of Administration, Director of Public Works, and Director of Public Safety. Lisa Baldelli-Hunt: Mayor of Woonsocket (2013-present). Previously served four terms as a state representative (2007-2013).

Christopher Beauchamp: Member of the Woonsocket City Council (2007-present).

John Beauregard: Member of the North Smithfield Town Council (2016-2018), Council President (2016-2018).

Robert Boucher: Member of the North Smithfield Town Council (2014-2016), Council President (2014-2016).

Albert Brien: Member of the Woonsocket City Council (2011-2016), Council President (20142016).

Jon Brien: Member of the Woonsocket City Council (2017-present), Council Vice President (2017- present). Previously served as a State Representative (2007- 2012).

Joseph Casali: President, Joe Casali Engineering, Inc. Served as a consultant to North Smithfield.

Christine Chamberland: Woonsocket Finance Director (2014-present). She has worked in the Woonsocket Finance Department since 1991, beginning her career with the city as an Assistant Controller.

Richard Coen: Partner, Burns and Levinson. Served as Counsel to Woonsocket during the dispute.

Sean Coffey: Partner, Burns and Levinson. Served as Counsel to Woonsocket during the dispute.

Janet Coit: Director, Rhode Island Department of Environmental Management (2011- present).

Anthony Cottone: Counsel to North Smithfield during the dispute.

James Cournoyer: Member of the Woonsocket City Council (2016-present). Previously

Chairman of the Woonsocket Wastewater Treatment Advisory Committee (2011).

John DeSimone: Woonsocket Solicitor (2017-present). Previously served as a RI State Representative (1993-2017) and House Majority Leader (2014-2017).

Marc Dubois: Member of the Woonsocket City Council (2011-2013). 
Paul Eisenhardt: Owner of the Eisenhardt Group (based in Port Townsend, Washington).

Served as a consultant to Woonsocket.

Robert Ericson: North Smithfield Town Planner (2009-2016).

Gary Ezovski: North Smithfield Town Administrator (2016- present).

Leo Fontaine: Mayor of Woonsocket (2009-2013).

Daniel Gendron: Member of the Woonsocket City Council (2009- present), Council President (2016-present).

Paulette Hamilton: North Smithfield Town Administrator (2008-2016).

David Igliozzi: North Smithfield Solicitor (2015- present). Partner, Igliozzi and Reis, LLC.

Roger Jalette: Member of the Woonsocket City Council (1995-2001) and (2007-2016).

Angelo Liberti: Chief of Surface Water Protection, Rhode Island Department of Environmental Management (1999- present).

Richard Licht: RI Superior Court Judge (2014- present). Previously served as Director of Administration (2011-2014), Lieutenant Governor (1985-1989) and in the RI State Senate (19731984).

Michael Marcello: Woonsocket Solicitor (2013-2016). Currently a partner at Lewis Brisbois.

Previously served as Rhode Island State Representative (2008-2016).

Sheila McGauvran: Woonsocket Public Works Director (2011-2013).

Thomas McGee: Member of the North Smithfield Town Council (2010-2014) and (2016-2018).

Robert Moreau: Member of the Woonsocket City Council (2012-2016).

Brian Newberry: State Representative from North Smithfield (2008- present). House Minority Leader from May 2011 through November 2016.

Robert Phillips: State Representative from Woonsocket (2011- present).

John Ward: Member of the Woonsocket City Council (2005-2013), Council President (2009-2013).

Paul Zwolenski: Member of the North Smithfield Town Council (2004-present). 


\section{Exhibit 2}

\section{Timeline of Major Events}

December 7, 1977- The City of Woonsocket and Town of North Smithfield signed a thirty-year interjurisdictional agreement (IJA) for waste disposal service.

June 27, 2008- Woonsocket entered into a consent agreement with the Department of Environmental Management (DEM) that included new limits for nitrogen, phosphorus, and other performance standards by March 31, 2014.

January 18, 2011- The Woonsocket City Council passed a resolution paying the plant operator Veolia up to $\$ 250,000$ a year for system upgrades in order to comply with the DEM consent agreement.

March 3, 2011 - Woonsocket entered into a modified consent agreement with the DEM.

August 11, 2011 - Woonsocket Mayor Leo Fontaine signed the ordinance that provided for the issuance of wastewater revenue bonds in an amount not to exceed $\$ 4,000,000$. During the City Council work session, members first discussed the possibility of charging a host fee to the neighboring communities.

November 21, 2011 - Woonsocket mayor Leo Fontaine signed the ordinance that approved the financing of improvements to the treatment plan in an amount not to exceed \$26 million.

December 19, 2011 - The Woonsocket City Council tabled a resolution that would have amended the the IJAs with North Smithfield, Bellingham, and Blackstone.

February 20, 2012 - The Woonsocket City Council passed a resolution instructing the mayor and director of public works to draft amended IJAs for the three jurisdictions. This resolution included host fees for each community, represented as a percentage of the plant improvement cost. North Smithfield would be responsible for $7 \%$, Bellingham $2.75 \%$, and Blackstone $1.5 \%$. Each town had twenty business days to respond. They would either accept the new agreements or proceed with termination.

March 15, 2012- The Woonsocket delegation to the RI State House introduced legislation delaying implementation of the DEM standards until after December 2017. This measure did not make it out of the legislature. The DEM gave a ten-month extension for Woonsocket to comply. 
March 4, 2013- The Woonsocket City Council passed a revised resolution (in place of the $2 / 20 / 12$ one) instructing the mayor and director of public works to draft amended IJAs for the three jurisdictions. This resolution specified the following dollar amounts for the host fees: $\$ 194,000$ for North Smithfield, \$76,000 for Blackstone, and \$42,000 for Bellingham. It also directed the host fees to Woonsocket's general fund. North Smithfield had not provided a response to the original resolution.

October 21, 2013 - The Woonsocket director for the Department of Public Works sent the North Smithfield administrator an official three-year notice of termination.

February 24, 2015- Woonsocket Mayor Lisa Baldelli-Hunt signed the ordinance that approved the City's borrowing of a maximum of \$14 million to finance plant improvement.

January 14, 2016- Woonsocket sent North Smithfield a letter describing damages the town would incur in the event of service termination.

March 2, 2016- North Smithfield Representative Brian Newberry proposed legislation that would create a regional authority to govern the wastewater treatment plant. This measure did not make it out of the legislature.

April 4, 2016- The North Smithfield Town Council passed a resolution authorizing the Town Solicitor to demand arbitration under the IJA with Woonsocket. Woonsocket declined to proceed with arbitration.

July 25, 2016- North Smithfield filed suit against Woonsocket in Rhode Island Superior Court.

September 13, 2016- Superior Court Judge Richard Licht ordered a motion to stay. He advised the two jurisdictions to engage in confidential, non-binding mediation.

October 27, 2016- The first Court-scheduled mediation took place between Woonsocket and North Smithfield.

December 5, 2016- The North Smithfield Town Council authorized the Town Administrator to establish a liaison with the City of Woonsocket to confidentially discuss the wastewater agreement.

April 17, 2017- The North Smithfield Town Council voted to accept the terms of the settlement agreement and authorize the town administrator to sign the new IJA. The Woonsocket City Council followed suit on May 15, 2017. The two jurisdictions retroactively implemented the 
agreements, with an effective start date of June 30, 2014. The amended IJA will expire on March 31, 2035. 


\section{Instructor's Manual}

\section{Synopsis}

From 2012-2017, the communities of Woonsocket and North Smithfield engaged in a protracted dispute concerning wastewater disposal. For thirty years, the two jurisdictions had maintained a signed service agreement. Following its expiration, however, Woonsocket imposed a new host fee on North Smithfield. Woonsocket needed to upgrade the facility in order to comply with mandates from the Rhode Island Department of Environmental Management. Over the next five years, leaders from both jurisdictions vociferously fought over the new fee. At the same time, leaders within communities experienced their own divisions. This case study highlights the challenges that leaders in both communities faced as they sought to resolve the conflict.

\section{Target Audience and Level}

This case is appropriate for graduate and executive level courses in environmental policy, communication, and leadership.

\section{Learning Objectives}

- Acquire knowledge about an example of an inter-jurisdictional agreement.

- Understand the roles and responsibilities of a host community in maintaining a regional facility.

- Evaluate the implementation of a new provision on the part of the host community.

- Analyze the response of stakeholders to the escalating situation.

- Evaluate the effectiveness of public officials in resolving the conflict.

\section{Discussion Questions and Answers}

- Do you think that Woonsocket, North Smithfield, and the other two municipalities (Bellingham and Blackstone) did an effective job of devising and implementing the interjurisdictional agreement?

o Pros: The jurisdictions formed their arrangement in line with Environmental Protection Agency standards and Rhode Island General Laws. For the next 30 years, there were no problems.

o Cons: In 2008 (following the consent agreement with the Rhode Island Department of Environmental Management), Woonsocket learned that the facility would require upgrades. Woonsocket did not consult with North Smithfield about cost allocations pertaining to plant improvements. The jurisdictions never fully implemented a regional board consisting of all participating communities.

- What were the roles and responsibilities of Woonsocket in maintaining a regional facility? 
o Woonsocket was responsible for keeping the facility in compliance with the latest environmental standards. This included maintain the contracts with the private firm that performed the necessary upgrades.

o Woonsocket had to deal with the consequences of hosting the plant, including decreased property values for homes and businesses in its proximity.

- How well did Woonsocket implement the new host fee?

o Woonsocket imposed the new host fee without first consulting the other participating municipalities.

o There was a lack of agreement between the City Council members and the administration.

o Woonsocket was the only community in Rhode Island to charge a host fee.

o Woonsocket gave the other communities only 20 business days to make a decision about continuing their usage of the facility. As the dispute continued, this time limit was rendered meaningless.

o The host fee was directed to the City's general fund, rather than the annual debt on plant improvements. This might be considered a violation of the spirit of the agreement, depending on one's point of view.

o There was confusion among City officials about whether the clock had started ticking on the three-year termination notice to North Smithfield.

- Do you think that officials in North Smithfield responded effectively to the new host fee? What would you have done differently?

o North Smithfield initially criticized the Rhode Island Department of Environmental Management for imposing stricter standards during a time of extreme economic challenge.

o North Smithfield contracted with a local engineering firm to examine possible alternatives to remaining with the Woonsocket facility. Sought to do their due diligence.

o The Town Council opted to hold up the easement on a bike path as a way of getting back at Woonsocket. The Town Council President publicly referred to the Woonsocket officials as a "bunch of gangsters."

- A State Representative from North Smithfield proposed legislation (unsuccessfully) requiring the facility to be governed by a regional board of directors, rather than solely by Woonsocket. This was intended to correct a deficiency in the implementation of the original agreement.

o North Smithfield requested arbitration, per the original agreement. Woonsocket refused to cooperate, so the town filed in Rhode Island Superior Court. The two jurisdictions ended up settling on the new agreement through informal meetings.

- Do you think that officials at the Rhode Island Department of Environmental Management responded effectively to the new host fee?

o The DEM testified against the legislation proposed by Woonsocket State Representatives to delay implementation of the standards. However, the department did give the city a two-year extension (until January 2017) to comply. 
o The Clean Water Finance Agency provided a \$30 million loan to finance upgrades to the plant.

o The DEM commented that compliance went smoothly from that point on, however, the other jurisdictions were not yet on board with the new host fee.

The DEM only found out about the host fee after Woonsocket started added it to bills for the neighboring communities.

o An official from the DEM did not think that it was fair for Woonsocket to impose a host fee. However, there was no legal basis for preventing such a move.

- Do you think that officials in Woonsocket responded effectively to criticism of the new host fee?

o State Representatives from Woonsocket attempted (unsuccessfully) to delay implementation of the new environmental standards via legislation until after December 31, 2017.

o There were continued disagreements among Woonsocket officials (City Council v. administration) about the implementation of the host fee.

o Officials - particularly two of the City Council Members proclaimed that Woonsocket should be able to do what they wanted with the fees since they were the ones hosting.

o The City threatened to "shut off the spigot" even though that was not a realistic option.

o The Woonsocket City Council directly addressed the residents of North Smithfield about the desire to maintain an agreement, with the new host fee. Soon after, the administration sent the town alerting them to the consequences of exiting. The letter contained unrealistic consequences (e.g., State and federal agencies would impose fines on North Smithfield).

o Woonsocket opposed North Smithfield's attempt to form a regional board, viewing it as a confiscation of their property.

- Can you foresee potential future problems with the inter-jurisdictional agreement?

o Woonsocket allocated its host fee to the general fund, which did not sit well with North Smithfield.

o Although the new agreement (like the previous one) designated the formation of a regional board, no such entity existed.

o The new agreement maintained the same provisions as before regarding the implementation of improvements and dispute resolutions. These same stipulations did not prevent Woonsocket from imposing the new host fee in the first place. 


\section{Theory Discussion}

\section{Introduction}

Interlocal agreements ${ }^{81}$ "allow two or more local units to cooperate on specific public goods and services without the need for the partners to consolidate additional services or governmental structures." 82 The existence of such agreements is made possible through the fragmented system of government found in the United States. Ostrom argued that the work of independent local governments allowed for innovation and an efficient marketplace of public services. ${ }^{83}$ Andrew wrote that most agreements were made in response to state and federal mandates. ${ }^{84}$ Zeemering articulated two major types of relationships for agreements. The buyer-seller relationship is one which one government pays a fee to another government for producing, staffing, and managing the service. The other form is a joint powers authority, which "allows two or more governments to create a quasi-independent public entity that is jointly governed and managed by the participating governments." 85 Joint facilities (or assets) may include such entities as shared public buildings and water treatment facilities. ${ }^{86}$

Williamson provided two categories of services subject to agreements, consisting of system maintenance or lifestyle functions. System maintenance includes various forms of infrastructure, such as roads, water distribution and solid waste disposal. Lifestyle functions involve "social and life opportunities" like education, public safety, parks and recreation, and economic development. He writes that communities are more willing to engage in maintenance

81 These are also known as intermunicipal, intergovernmental, or interjurisdictional agreements.

${ }^{82}$ Kurt Thurmaier and Curtis Wood, "Interlocal Agreements as an Alternative to Consolidation," in CityCounty Consolidation and Its Alternatives: Reshaping the Local Government Landscape, ed. Jered B. Carr and Richard C. Feiock (Armonk, NY: M.E. Sharpe, 2004), 113-30, cited in Eric S. Zeemering, "Governing Interlocal Cooperation: City Council Interests and the Implications for Public Management," Public Administration Review 68(2008), 732.

${ }^{83}$ Elinor Ostrom, "Analyzing Collective Action," Agricultural Economics 41(2010), 155-166, cited in Mildred E. Warner, "Municipal Size, Resources, and Efficiency: Theoretical Bases for Shared Services and Consolidation," in Municipal Shared Services and Consolidation: A Public Solutions Handbook, ed. Alexander C. Henderson (New York: Routledge, 2015), 4.

84 Simon A. Andrew, "Recent Developments in the Study of Interjurisdictional Agreements: An Overview and Assessment," State and Local Government Review 41(2009), 134.

${ }^{85}$ Eric S. Zeemering, "Managing Interlocal Contract and Shared Service Relationships," in Municipal Shared Services and Consolidation: A Public Solutions Handbook, ed. Alexander C. Henderson (New York: Routledge, 2015), 91.

${ }^{86}$ Ricardo S. Morse and Charles R. Abernathy, "Mapping the Shared Services Landscape," in Municipal Shared Services and Consolidation: A Public Solutions Handbook, ed. Alexander C. Henderson (New York: Routledge, 2015), 147. 
agreements, because "these services are neutral to the values of citizens and are perceived to be essential to the functioning of government." 87

In a 1971 article extolling the virtues of regionalization, Canham et al highlighted the efficiencies that would result from the formation of regionalized wastewater facilities. Three major purposes mentioned were:

"Reuse of wastewater for processes not requiring high quality water will reduce treatment costs. Reusing waste products will provide more beneficial resource allocation in addition to reducing waste discharges. Recycling of wastewater will reduce pollution by eliminating discharges." 88

\section{Conditions for Success}

Scholars have identified several conditions necessary for the successful implementation of interlocal agreements. Chen and Thurmaier identified three critical factors: reciprocity (trust between collaborators), equity (equal sharing of costs and benefits), and shared understanding of goals. ${ }^{89}$ Trust is necessary since local officials need to cede some of their authority to achieve regional cooperation. ${ }^{90}$ Furthermore, there needs to be a credible commitment to the agreement, otherwise one or more of the parties might defect and free ride off the efforts of others. ${ }^{91}$ Parties to the agreement also need to attain cooperation in order to gain a mutual economic advantage. ${ }^{92}$

${ }^{87}$ Oliver E. Williamson, Metropolitan Political Analysis (New York: Free Press, 1971), cited in Jered B. Carr and Christopher V. Hawkins, "The Costs of Cooperation: What the Research Tells Us about Managing the Risks of Service Collaborations in the U.S.," State and Local Government Review 45(2013), 227.

${ }^{88}$ Erwin D. Canham et al, "The Environmental Battle and the Regional Management of Wastewater Utilities," Journal of the Water Pollution Control Federation 43(1971), 9.

${ }^{89} \mathrm{Yu}$-Che Chen and Kurt Thurmaier, "Interlocal Agreements as Collaborations: An Empirical Investigation of Impetuses, Norms, and Success," American Review of Public Administration 39(2009), 536552, cited in Daniel E. Bromberg, "Do Shared Services Achieve Results? The Performance of Interlocal Agreements," in Municipal Shared Services and Consolidation: A Public Solutions Handbook, ed. Alexander C. Henderson (New York: Routledge, 2015), 110.

${ }^{90}$ Elisabeth R. Gerber and Clark C. Gibson, "Balancing Regionalism and Localism: Political Representation in American Transportation Policy," (Paper presented at the Harris School Workshop in Political Economy, Chicago, May 2008), cited in Sung-Wook Kwon and Richard C. Feiock, "Overcoming the Barriers to Cooperation: Intergovernmental Service Agreements," Public Administration Review 70(2010), 879 .

${ }^{91}$ Richard C. Feiock, "Metropolitan Governance and Institutional Collective Action," Urban Affairs Review 44(2009), 356-377, cited in Samuel Nunn and Mark S. Rosentraub, "Dimensions of Interjurisdictional Cooperation," Journal of the American Planning Association 63(1997), 228-29.

92 Erwin D. Canham et al, "The Environmental Battle and the Regional Management of Wastewater Utilities," Journal of the Water Pollution Control Federation 43(1971), 12. 
The signing of an agreement should not mark the end of interaction among the parties. Specifying the tasks of the agreement may require extensive communication. ${ }^{93}$ Government officials should view the agreements as "relationships that require active management and regular oversight." 94 Local officials need to remain actively engaged in order to successful manage the agreement. ${ }^{95}$

\section{Variables Affecting Implementation}

The literature illustrates a host of variables that affect the likelihood of success in implementing an agreement. At the most basic level, the higher the number of municipalities involved, the greater the likelihood for conflict. ${ }^{96}$

The characteristics of the localities themselves matter too. It is difficult to coordinate an agreement when there is major variation in demographics, resource levels, or municipal institutions. ${ }^{97}$ Under such circumstance, the "stronger partner" will seek to attain most of the gains, while the "weaker partner" will have little incentive to formalize the agreement. Governments that are "similarly situated" have an increased probability of reaching a suitable deal. ${ }^{98}$ The internal political structure of the participating municipalities also play a role. This includes the form of government and associated personalities. For example, a city council

${ }_{93}$ Jered B. Carr and Christopher V. Hawkins, "The Costs of Cooperation: What the Research Tells Us about Managing the Risks of Service Collaborations in the U.S.," State and Local Government Review 45(2013), 227.

${ }^{94}$ Eric S. Zeemering, "Managing Interlocal Contract and Shared Service Relationships," in Municipal Shared Services and Consolidation: A Public Solutions Handbook, ed. Alexander C. Henderson (New York: Routledge, 2015), 88.

${ }^{95}$ Eric S. Zeemering, "Managing Interlocal Contract and Shared Service Relationships," in Municipal Shared Services and Consolidation: A Public Solutions Handbook, ed. Alexander C. Henderson (New York: Routledge, 2015), 100.

${ }^{96}$ Erwin D. Canham et al, "The Environmental Battle and the Regional Management of Wastewater Utilities," Journal of the Water Pollution Control Federation 43(1971), 12.

${ }^{97}$ Kelly LeRoux, "Nonprofit Community Conferences: The Role of Alternative Regional Institutions in Interlocal Service Delivery," State and Local Government Review 40(2008), 160-72; Ronald J. Oakerson, "The Study of Metropolitan Governance," in Metropolitan Governance: Conflict, Competition and Cooperation, ed. Richard C. Feiock (Washington, DC: Georgetown University Press, 2004), 17-45; Annette Steinacker, "Game Theoretic Models of Metropolitan Cooperation," in Metropolitan Governance: Conflict, Competition and Cooperation, ed. Richard C. Feiock (Washington, DC: Georgetown University Press, 2004), 46-66, all cited in Jered B. Carr and Christopher V. Hawkins, "The Costs of Cooperation: What the Research Tells Us about Managing the Risks of Service Collaborations in the U.S.," State and Local Government Review 45(2013), 226.

98 Annette Steinacker, "Game Theoretic Models of Metropolitan Cooperation," in Metropolitan Governance: Conflict, Competition and Cooperation, ed. Richard C. Feiock (Washington, DC: Georgetown University Press, 2004), 46-66, cited in Sung-Wook Kwon and Richard C. Feiock, "Overcoming the Barriers to Cooperation: Intergovernmental Service Agreements," Public Administration Review 70(2010), 879. 
might worry about a loss of control, while a mayor might view the agreement as an opportunity to increase his or her own visibility. ${ }^{99}$

The nature of the public services contained in the agreement play a role in its enactment. Asset specificity pertains to whether specialized investments are needed to deliver the goods or service, while measurement difficulty encompasses how easily performance measures can be identified and the extent to which vendors can be expected to meet all their obligations in delivering the service. ${ }^{100}$ It is difficult to attain cost savings when services are highly specialized and difficult to measure. ${ }^{101}$

Finally, regulations at the state level may inhibit or encourage collaborative action. Such guidelines may include incentives for participation or added levels of red tape. ${ }^{102}$

$\underline{\text { Areas of Potential Conflict }}$

Potential conflicts may result from changing roles and responsibilities, enforcement and negotiation costs, and changes to the original agreements.

99 Richard C. Feiock, "Metropolitan Governance and Institutional Collective Action," Urban Affairs Review 44(2009), 356-377, cited in Daniel E. Bromberg, "Do Shared Services Achieve Results? The Performance of Interlocal Agreements," in Municipal Shared Services and Consolidation: A Public Solutions Handbook, ed. Alexander C. Henderson (New York: Routledge, 2015), 112.

100 Jered B. Carr, Kelly LeRoux, and Manoj Shrestha, "Institutional Ties, Transaction Costs, and External Service Production," Urban Affairs Review 44(2009), 403-427, cited in Jered B. Carr and Christopher V. Hawkins, "The Costs of Cooperation: What the Research Tells Us about Managing the Risks of Service Collaborations in the U.S.," State and Local Government Review 45(2013), 228-29.

101 Trevor L. Brown, Matthew Potoski and David M. Van Slyke, "Managing Public Service Contracts: Aligning Values, Institutions, and Markets," Public Administration Review 66(2006): 323-331; Jered B. Carr, Kelly LeRoux, and Manoj Shrestha, "Institutional Ties, Transaction Costs, and External Service Production," Urban Affairs Review 44(2009), 403-27, both cited in Jered B. Carr and Christopher V. Hawkins, "The Costs of Cooperation: What the Research Tells Us about Managing the Risks of Service Collaborations in the U.S.," State and Local Government Review 45(2013), 229.

102 Richard C. Feiock, "Metropolitan Governance and Institutional Collective Action," Urban Affairs Review 44(2009), 356-377, cited in Daniel E. Bromberg, "Do Shared Services Achieve Results? The Performance of Interlocal Agreements," in Municipal Shared Services and Consolidation: A Public Solutions Handbook, ed. Alexander C. Henderson (New York: Routledge, 2015), 112. 
Since local officials have to cede their own authority in order to come to agreement, it makes it more difficult to target benefits directly to their constituents. ${ }^{103}$ In addition, local government personnel might consider shared services as a threat to their own employment. ${ }^{104}$

There are costs associated with negotiating and monitoring the agreement. Parties need to make credible commitments not to renege on the agreement. ${ }^{105}$ The absence of clearly identified joint gains resulting from the arrangement also muddles the implementation process. ${ }^{106}$ Conflict can arise when local governments have difficulty dividing and distributing the benefits that accrue from the agreement. ${ }^{107}$

${ }^{103}$ Elisabeth R. Gerber and Clark C. Gibson, “Balancing Regionalism and Localism: Political Representation in American Transportation Policy," (Paper presented at the Harris School Workshop in Political Economy, Chicago, May 2008), cited in Sung-Wook Kwon and Richard C. Feiock, "Overcoming the Barriers to Cooperation: Intergovernmental Service Agreements," Public Administration Review 70(2010), 879 .

${ }_{104}$ Anthony Brand, The Politics of Shared Services: What are the Underlying Barriers to a More Successful Shared Services Agenda? (London: New Local Government Network, 2006), cited in Tony J. Carrizales et al, “Targeting Opportunities for Shared Police Services," Public Performance \& Management Review 34(2010), 257.

105 Mark Granovetter, “The Impact of Social Structure on Economic Outcomes," Journal of Economic Perspectives 19(2005), 33-50, cited in Sung-Wook Kwon and Richard C. Feiock, "Overcoming the Barriers to Cooperation: Intergovernmental Service Agreements," Public Administration Review 70(2010), 879. 106 Oliver E. Williamson, "The Economics of Organization: The Transaction Cost Approach," American Journal of Sociology 87(1981), 548-77; Richard C. Feiock, "The Institutional Collective Action Framework," Policy Studies Journal 41(2013), 397-425; William Hatley, "The Art of Collaboration: Interlocal Collaboration in the Provision of Fire Services in the Detroit Area," PhD diss., (Wayne State University, 2010), all cited in Jered B. Carr and Christopher V. Hawkins, "The Costs of Cooperation: What the Research Tells Us about Managing the Risks of Service Collaborations in the U.S.," State and Local Government Review 45(2013), 226.

107 Annette Steinacker, "Game Theoretic Models of Metropolitan Cooperation," in Metropolitan Governance: Conflict, Competition, and Cooperation, ed. Richard C. Feiock (Washington, DC: Georgetown University Press, 2004), 46-66; Annette Steinacker, “The Institutional Collective Action Perspective on Self-Organizing Mechanisms: Market Failures and Transaction Cost Problems," in Self-Organizing Federalism: Collaborative Mechanisms to Mitigate Institutional Collective Action, ed. Richard C. Feiock and John T. Scholz (Cambridge, UK: Cambridge University Press, 2010), 51-72; Richard C. Feiock, "Rational Choice and Regional Governance," Journal of Urban Affairs 29(2007), 47-63; Christopher V. Hawkins, "Competition and Cooperation: Local Government Joint Ventures for Economic Development," Journal of Urban Affairs 32(2010), 253-275, all cited in Christopher V. Hawkins and Jered B. Carr, "The Costs of Services Cooperation," in Municipal Shared Services and Consolidation: A Public Solutions Handbook, ed. Alexander C. Henderson (New York: Routledge, 2015), 20. 
In the event that there is a shift away from the original agreement, the parties need to devise a transition plan. In such a case, there needs to be adequate time to transfer knowledge about such tasks as operations, staffing, and equipment. ${ }^{108}$

\section{Approaches to Mitigating Conflict}

The interactions among public officials and the way in which they organize their work serve to mitigate potential conflicts. The Institutional Collective Action (ICA) framework, which derives from economics, deals with the costs and benefits of organizing and maintaining cooperation. ${ }^{109}$ Under this framework, social networks may help facilitate cooperation by acting as a venue for information exchanges and reducing ambiguities. ${ }^{110}$ According to Zeemering, "Good working relationships among government officials can help city officials identify problems with interlocal agreements before they escalate to a point at which relationships are damaged."111 Social networks facilitate familiarity and mutual dependencies, which increases durability of agreements. ${ }^{112}$ The notion of social networks may be applied to self-organizing bodies supporting shared service agreements. These include regional authorities, regional organizations and collaborative groups or councils. ${ }^{113}$

${ }^{108}$ Michael R. Hattery, "Service-Level Consolidation and Sharing Arrangements," in Municipal Shared Services and Consolidation: A Public Solutions Handbook, ed. Alexander C. Henderson (New York: Routledge, 2015), 67.

${ }^{109}$ Eric S. Zeemering, "Managing Interlocal Contract and Shared Service Relationships," in Municipal Shared Services and Consolidation: A Public Solutions Handbook, ed. Alexander C. Henderson (New York: Routledge, 2015), 90-91.

110 See Jered B. Carr, Kelly LeRoux, and Manoj Shrestha, "Institutional Ties, Transaction Costs, and External Service Production," Urban Affairs Review 44(2009), 403-427; Richard C. Feiock, Annette Steinacker, and Hyung-Jun Park, "Institutional Collective Action and Economic Development Joint Ventures," Public Administration Review 69(2009), 256-270; Richard C. Feiock, et al, "Collaborative Networks Among Local Elected Officials: Information, Commitment, and Risk Aversion," Urban Affairs Review 46(2010), 241-262; Manoj Shresta and Richard C. Feiock, “Governing U.S. Metropolitan Areas: SelfOrganizing and Multiplex Service Networks," American Politics Research 37(2009), 801-823, all cited in Eric S. Zeemering, "Governing Interlocal Cooperation: City Council Interests and the Implications for Public Management," Public Administration Review 68(2008), 91-92.

111 Eric S. Zeemering, "Governing Interlocal Cooperation: City Council Interests and the Implications for Public Management," Public Administration Review 68(2008), 91-92.

112 Mark Granovetter, “The Impact of Social Structure on Economic Outcomes," Journal of Economic Perspectives 19(2005), 33-50, cited in Sung-Wook Kwon and Richard C. Feiock, "Overcoming the Barriers to Cooperation: Intergovernmental Service Agreements," Public Administration Review 70(2010), 879.

113 Richard C. Feiock, "Metropolitan Governance and Institutional Collective Action," Urban Affairs Review 44(2009), 356-377, cited in Jered B. Carr and Christopher V. Hawkins, "The Costs of Cooperation: What the Research Tells Us about Managing the Risks of Service Collaborations in the U.S.," State and Local Government Review 45(2013), 231-32. 
The objective and arrangement of the work also function to alleviate conflicts. It is optimal to have a "singular overriding goal," such as cost savings, improved service quality, 114 or adding new services. ${ }^{115}$ However, it is important to keep in mind that even the simple goal of cost savings might make coming to an agreement more difficult due to differing expectations. Finally, collaborative service agreements should maintain flexibility in order to leave the door open to future negotiation. Such options include memoranda of agreement, memoranda of understanding, and mutual aid agreements. ${ }^{116}$

\section{Teaching Strategy}

This case could be taught over the course of one or two class sessions. The one class approach would be to have students read the case then have a discussion using the questions as a guide. The other approach would be to have students engage in a role-playing simulation using a twopart modified version of the case. The roles include officials from each of the jurisdictions, as well as the Department of Environmental Management. Following the role-play, participants learn about how the real-life events further unfolded. Please see the attached role-playing document for further information.

${ }^{114}$ Richard C. Feiock and Jered B. Carr, "Incentives, Entrepreneurs, and Boundary Change: A Collective Action Framework," Urban Affairs Review 36(2001), 382-405; Kelly LeRoux and Sanjay Pandey, "City Managers, Career Incentives and Municipal Service Decisions: The Effects of Managerial Ambition on Interlocal Service Delivery," Public Administration Review 71(2011), 627-36, both cited in Jered B. Carr and Christopher V. Hawkins, "The Costs of Cooperation: What the Research Tells Us about Managing the Risks of Service Collaborations in the U.S.," State and Local Government Review 45(2013), 226-227.

115 Samuel Nunn and Mark S. Rosentraub, "Dimensions of Interjurisdictional Cooperation," Journal of the American Planning Association 63(1997), 205-19, cited in Jered B. Carr and Christopher V. Hawkins, "The Costs of Cooperation: What the Research Tells Us about Managing the Risks of Service Collaborations in the U.S.," State and Local Government Review 45(2013), 226-227.

116 Simon A. Andrew, "Regional Integration through Contracting Networks: An Empirical Analysis of Institutional Collective Action Framework" Urban Affairs Review 44(2009), 378-402, cited in Jered B. Carr and Christopher V. Hawkins, "The Costs of Cooperation: What the Research Tells Us about Managing the Risks of Service Collaborations in the U.S.," State and Local Government Review 45(2013), 230-31. 
Wastewater Dispute Role-Play Overview

Parts:

- Mayor of Wintervale (Parts 1 and 2)

- Council Member from Wintervale (Parts 1 and 2)

- Administrator of Newglen (Part 2 only)

- Council Member from Newglen (Part 2 only)

- Administrator from the Department of Environmental Management (DEM) (Parts 1 and 2)

Objective: This role-play will give participants the opportunity to experience a conflict between two jurisdictions, based on a series of real life events. The first part deals with the process by which Wintervale formulated a new inter-jurisdictional agreement (IJA). In the second part, the two communities (Wintervale and Newglen) grapple with implementing the agreement.

Following the role-play, participants learn about how the real-life events further unfolded. 


\section{Wastewater Treatment Scenario- Part One}

For thirty years, Wintervale maintained an inter-jurisdictional agreement (IJA) for wastewater disposal with three jurisdictions. Under the terms of the arrangement, the wastewater facility was located in Wintervale. The three other communities contracted with Wintervale for service.

The contract between Wintervale and the jurisdictions contained several significant provisions concerning the governance of the facility.

6) The thirty-year timeframe represented the minimum commitment. Upon the conclusion of that period, the parties would remain in the contract unless they arranged for termination. Either of the parties would be required to provide three years notice to end the contract.

7) If it became necessary for capital improvements to take place, Wintervale would consult with the jurisdictions to "determine jointly the nature of the improvements, the cost and financing thereof, the allocation of such costs among participating municipalities and other factors." Improvements and cost allocations would only proceed in accordance with the agreement.

8) The contract called for the creation of an official board for adopting the facility's policies and programs. The board would consist of at least 10 representatives total across all participating municipalities, based on the cost incurred by the jurisdiction.

9) If Wintervale contemplated any increases in expenditures for plant maintenance or operation resulting in increased costs to the jurisdictions, the parties would hold a joint conference.

10) In the event of disagreement, the Wintervale City Council and the User Town's Board of Sewer Commissioners would convene to work on the matter. If discord continued, either of the jurisdictions could file a request for arbitration.

Thirty years following the original signing, the communities had not drafted a replacement agreement. Thus, everything continued as usual, subject to the three-year termination by either side.

The Rhode Island Department of Environmental Management Imposes New Mandates; Wintervale Plans for Facility Upgrades

After the initial thirty-year period passed, Wintervale entered into a new consent agreement with the Department of Environmental Management (DEM) relating to the wastewater treatment plant. This agreement gave Wintervale six years to meet new limits for nitrogen, phosphorus and other performance standards. Wintervale would need financing in order to upgrade the plant in order to comply with the new DEM mandates. 
Wintervale Plans for Facility Upgrades, but Not Everyone is on the Same Page

Three years following the signing of the consent agreement, the Wintervale City Council considered an ordinance providing for the issuance of wastewater revenue bonds in an amount not to exceed $\$ 4,000,000$. A Council member and city administrator engaged in a testy exchange during a City Council meeting. The two went back and forth about Wintervale's costs associated with the reserve capacity for the plant upgrades.

Further strife between the City Council and administration was on display during the second round of discussion for the $\$ 4$ million finance ordinance during the following month's meeting. In particular, three members of the Wintervale City Council complained about the manner in which the administration had handled the ordinance. One did not understand the urgency of passing the ordinance that night or why the IJAs were not part of the package given to the Council. The mayor and a Wintervale administrator explained that the ordinance was necessary for lining up the financing in order to comply with the DEM consent order. The administration did not include the new IJAs because those were still in draft form.

Despite the tensions, the City Council and mayor approved the ordinance. At this point, none of the other communities had participated in any plant discussions.

\section{The First Mention of a Potential Plant Host Fee}

Three months later, the Wintervale City Council held a work session regarding progress on the continually fraught area of new IJAs with the three served communities. Despite reservations raised by Wintervale's consultant, two Council members complained that Wintervale had the burden of hosting the plant and should therefore be able to charge a host fee to the three jurisdictions. Wintervale would be the first community in Rhode Island to impose a host fee for the use of its wastewater treatment plant. The consultant and Wintervale administrator warned that changing the IJAs to include a potential host fee could put the City at risk of losing out on state financing.

That same day, Wintervale's mayor signed an ordinance approving the financing of improvements to the treatment plant in an amount not to exceed \$26 million. 


\section{Guiding Questions for Part One}

Your challenge is to devise a plan for Wintervale to craft new IJAs with the three communities, given the state-mandated upgrades to the wastewater treatment facility.

1) Describe Wintervale's approach to devising a new IJA.

2) What provisions existed for consultation between Wintervale and the other jurisdictions? Describe the interactions that took place among them.

3) What is the DEM's role in this? (Who did DEM communicate with about the new facility standards?)

4) Why were the Wintervale City Council and administration not on the same page? How could they better communicate?

5) Wintervale was set to be the first community in RI to impose a host fee. What are your thoughts on this?

6) Discuss potential areas of conflict. What is the problem to be solved? What are your suggested alternatives to actions taken? 
Wastewater Scenario Role Play (Part One)

Role: You are the mayor of Wintervale. Previously, you served several terms on the City Council.

Here are some additional details pertaining to part one of the scenario:

- Wintervale needed financing in order to upgrade the plant in compliance with the new DEM mandates. The City required assurances that the neighboring user communities would continue to contract for wastewater services.

- During the second round of discussion for the \$4 million finance ordinance, the mayor took issue with the Wintervale City Council's negative characterization of the process. The mayor noted that it had been three weeks since the first passage of the ordinance. In that time, none of the Council members contacted City Hall with questions, or otherwise expressed the need for a work session.

- During the work session, the mayor indicated that imposing a host fee on the neighboring communities could result in repercussions. 
Wastewater Scenario Role Play (Part One)

Role: You are a City Council member for Wintervale.

Here are some additional details pertaining to part one of the scenario:

- Here are examples of relevant RI General laws:

45-14-1- Power to Assess Charges- States that "each city and town is authorized and empowered to enact ordinances assessing users of sewers or sewer systems of the cities and towns, a charge for the use of the sewers or sewer systems in an amount that bears a reasonable relation to the cost to the city or town of the service rendered to the users"

46-12.2-10- RI Infrastructure Bank/Powers of Local Governmental Units- Allows for a local governmental unit to enter into agreements and charge fees for the use of any wastewater system.

- Two and a half years after Wintervale entered into the original consent agreement with the DEM, the City Council unanimously passed a resolution ${ }^{117}$ paying the wastewater facility operator up to $\$ 250,000 /$ year for system upgrades to reduce phosphorus.

117 While an ordinance requires Council and mayoral approval, resolution only requires single passage by the City Council. 
Wastewater Scenario Role Play (Part One)

Role: You are a long time administrator at the Rhode Island Department of Environmental Management in charge of managing water quality for the state.

Here are some additional details pertaining to part one of the scenario:

- The formation of the U.S. Environmental Protection Agency and passage of the Clean Water Act prompted the original IJA. Communities used federal funds for constructing municipal wastewater treatment plants. From there, communities formed regional commissions and IJAs for wastewater facility construction, operation, and maintenance.

- Wintervale entered into a modified consent agreement with the DEM three years after the original consent agreement. This agreement did not change the deadline for meeting the new standards.

- The Clean Water Finance Agency (part of the DEM) requires new IJAs in order to provide financing for plant upgrades. 
Wastewater Treatment Scenario- Part Two

\section{$\underline{\text { Other Jurisdictions Learn about Fee Increases }}$}

By the time Wintervale approved the $\$ 26$ million in financing for improvements to the treatment plant, neighboring communities were just beginning to learn about potential wastewater fee increases.

A couple of weeks later, at the Wintervale City Council meeting, officials discussed the controversial rollout of the proposed host fees. During the citizens "good and welfare" portion of the meeting, an official from Bluehaven complained that he had only just learned about the new host fees. Two of the Council members expressed concerns about the town's lack of knowledge regarding the new fee. The mayor wanted no further delays. Wintervale's counsel said that while he had already spoken to the attorneys for each of the three neighboring jurisdictions (Bluehaven, Belcrest, and Newglen) about IJA modifications, he lacked direction from the Council regarding next steps. One Wintervale Council member continued to impress upon the City's right to charge a host fee:

"Because Wintervale has established this phenomenal infrastructure, which, when we get this mandate that we have to improve our wastewater treatment by [the] DEM, that falls on Wintervale's shoulders... So the other communities are affected but this is Wintervale's problem, because it's Wintervale's wastewater treatment plant. It's not a regional plant."

Following a heated conversation among Council members and the administration, the Council decided to table the resolution that would have amended the IJA with the three jurisdictions. Despite the temporary tabling of the resolution, Wintervale's City Council continued to progress towards implementation of a host fee.

\section{The Wintervale City Council Formalizes the New Host Fees}

Two months later, the Wintervale City Council passed a resolution instructing the administration to draft amended IJAs for Newglen and neighboring users, with the host fees explicitly articulated. Each town's host fee was to represent a percentage of the cost of plant improvements, based on wastewater contributions, as follows:

- Newglen- $7 \%$

- Belcrest- $2.75 \%$

- Bluehaven- $1.5 \%$

Each town had 20 business days to accept the new agreement, after which time Wintervale intended to issue a three-year termination notice. The new agreement did not contain any provisions for discussion of the new fee structure. 


\section{Continued Interactions between Wintervale and the DEM}

At the following month's Wintervale City Council meeting, a Council member complained about their treatment by DEM, and the State of Rhode Island, in general: "The state right now, the way they're treating Wintervale, we've had our state aid cut, we've had more state mandates than ever before. They're mandating a wastewater treatment plant; they're mandating a water treatment plant. Everything's got to be done with no funding from them at all. When does it stop? When do they come and help us?"

Wintervale's delegation to the RI State House attempted to mitigate the situation. A couple of weeks later, three Representatives introduced a bill that called for Wintervale to delay implementation of the DEM standards by three additional years, due to financial constraints. A week later, the House Municipal Government Committee recommended passage, but no further action occurred. The DEM had testified against the bill, but negotiations with the City were already on-going regarding an additional extension and the DEM ended up giving Wintervale one last, two-year extension. From that point on, Wintervale's compliance was "smooth sailing," according to a DEM administrator.

\section{Wintervale Continues Working Toward Implementing a Host Fee}

Ten months pass. At a Wintervale City Council meeting, one of the members expressed his continued discontent with Newglen. He was bothered that Newglen had the means to undertake successful economic development thanks to Wintervale's comprehensive infrastructure. The member expressed this as evidence that Newglen should pay a premium in order to use the wastewater treatment plant.

Two months later, Wintervale's City Council unanimously passed a resolution instructing the mayor and director of public works to draft amended IJAs with all three towns. The new resolution contained two major changes. First, Wintervale would direct the host fee to the general fund, rather than the annual debt on plant improvements. Second, instead of outlining the host fee in terms of percentages, the new resolution specified the dollar amounts. Newglen would pay a host fee of $\$ 194,000$, Belcrest $\$ 76,000$, and Bluehaven $\$ 42,000$. Furthermore, Wintervale would increase the host fee on an annual basis by the CPI for all urban customers in the Boston area issued in July each year.

\section{Tensions Brew between Wintervale and Newglen}

Two months later, Newglen began to grapple with the issue of the new host fee during its own Council meetings. By this point, over a year had passed since the 20-day period of consideration. ${ }^{118}$ The town administrator remarked that the new fee did not go over well with

\footnotetext{
118 The two other jurisdictions promptly signed the new IJAs. However, Wintervale did have some ongoing difficulties with having Bluehaven pay their host fee in the first year of the agreement.
} 
any of the local officials. A new annual fee would raise the rates for users considerably. The administrator found that having the host fee directed to Wintervale's general fund was particularly troubling:

"I think that it would have been even more palatable, as disdainful as it was to have it [the host fee] at all, if it had gone back to the sewer fund to provide upgrades to the system that would not have to be borne by the ratepayers... But clearly the City [Wintervale] was in financial constraints and needed to garner as much additional revenue as possible... I know and was told unequivocally that you never comingle those funds."

The DEM was not aware of the host fee until after Wintervale started appending it to bills for the communities. Newglen contacted the DEM asking if this was legal. The DEM said there was nothing in the state regulations forbidding it-even though none of the other communities in RI charged a host fee for use of their treatment facilities. Finding a feasible alternative was not so simple. Meanwhile, Newglen's administrator said that, in general, there was a lot of friction between her and the Town Council on a number of issues. This made it difficult to negotiate with Wintervale in a civilized manner.

At the Wintervale City Council meeting two months later, three Council members confirmed with the mayor that the three-year cancellation notice had been sent to Newglen.

Two weeks later, during the Newglen Town Council meeting, members went into executive session regarding the wastewater agreement. No motions were made, or votes taken on the issue. This would mark just one of many instances in which the Newglen Town Council decided to deal with the matter behind closed doors. Since there were no motions or votes, there was no available public record of the session. Records of this and other executive sessions remain sealed indefinitely.

Wintervale officials discussed the status of the three-year notice once again during a subsequent City Council meeting. Although the mayor said that he had not heard any response from Newglen, one of the City Council members said that he had heard from the Newglen Town Council President that Wintervale would have a response within 30 days.

Additional time passed, and Newglen failed to approve the new IJA. A member from Wintervale's City Council member wanted to make clear during a meeting that Wintervale did not seek to "gouge its neighbors." The member also expressed impatience with Newglen's lack of response.

By the time the Wintervale City Council met once again the following month, Newglen was not any closer to signing onto the agreement. One of the Council members impressed upon the mayor the need to proceed with the termination notice. 
A couple weeks later, Wintervale's DPW Director sent out the official termination notice to the administrator of Newglen. The letter contained the threat: "As the Town [Newglen] is aware, the U.S. Environmental Protection Agency, the Rhode Island Department of Environmental Management and other federal and state agencies may impose fines or other penalties should the Town [Newglen] fail to ensure [in a timely manner] the proper disposal of its residents' wastewater immediately following the Wind-Down Period." 


\section{Guiding Questions for Part Two}

1) Who owns the plant? How was this determined?

2) Once Wintervale implemented host fees, describe the communications between that community and Newglen.

3) What was the timeframe for accepting the new IJA? How did this actually play out?

4) Describe the approach that Newglen took to examining the new IJA. What would you suggest?

5) What role did state representatives play in the process?

6) In what ways were the respective jurisdictions on the same page? In what ways were they not?

7) How would you go about resolving this dispute? 
Wastewater Scenario Role Play (Part Two)

Role: You are the mayor of Wintervale. Previously, you served several terms on the City Council.

Here are some additional details pertaining to part two of the scenario:

- During the Wintervale City Council meeting where officials decided to charge Newglen a host fee of $\$ 194,000$ (with an escalator), the mayor and DPW sparred with the Council. They argued about whether the fee was accurate in helping to cover a project estimated to cost $\$ 37$ million. It took time to convince the Council that this was correct. 
Wastewater Scenario Role Play (Part Two)

Role: You are a City Council member for Wintervale.

Here are some additional details pertaining to part two of the scenario:

- During the Wintervale City Council meeting where officials decided to charge Newglen a host fee of $\$ 194,000$ (with an escalator), the mayor and DPW sparred with the Council. They argued about whether the fee was accurate in helping to cover a project estimated to cost \$37 million. It took time to convince the Council that this was correct. 
Wastewater Scenario Role Play (Part Two)

Role: You are a long time administrator at the Rhode Island Department of Environmental Management in charge of managing water quality for the state.

Here are some additional details pertaining to part two of the scenario:

- There was no way to shut off service strictly to Newglen without closing down the entire system.

- Neither state nor federal agencies were going to impose fines on Newglen in this situation. 
Wastewater Scenario Role Play (Part Two)

Role: You are the administrator for Newglen.

Here are some additional details pertaining to part two of the scenario:

- At the time that neighboring communities were just beginning to learn about potential wastewater fee increases (not necessarily the host fee itself), the administrator had a letter published in a local paper. At the time, she blamed fee increases on the DEM mandate. The administrator wrote, "The R.I. Dept. of Environmental Management is imposing an unrealistic requirement in these uncertain economic times. It would seem to me that the emphasis should be focused on the state, which once again has placed an unfunded mandate on a city [City A] that is already struggling..."

- The administrator learned from DEM that there was no way to shut off service strictly to Newglen without closing down the entire system. However, constituents worried that this could actually happen.

- Newglen always paid its wastewater bills on time over the course of the dispute, with the exception of the host fees.

- Newglen had commissioned a local engineering firm to study wastewater treatment alternatives in the event of service termination with Wintervale. The firm recommended that Newglen use Wintervale's facility, as it was the most affordable option. 
Wastewater Scenario Role Play (Part Two)

Role: You are a Newglen Town Council member.

Here are some additional details pertaining to part two of the scenario:

- Newglen had commissioned a local engineering firm to study wastewater treatment alternatives in the event of service termination with Wintervale. The firm recommended that Newglen use Wintervale's facility, as it was the most affordable option.

- Over the three-year period of the dispute, the Newglen Town Council held executive sessions pertaining to wastewater on 19 occasions. 